\title{
Base-Mediated Ring-Contraction of Pyran Systems Promoted by Palladium and Phase-
}

\section{Transfer Catalysis}

\author{
Stuart Aiken, Orlando D. C. C. de Azevedo* ${ }^{* \dagger}$ Kieran Chauhan, Thomas Driscoll,
} Paul I. Elliott, Christopher D. Gabbutt, and B. Mark Heron ${ }^{* \ddagger}$

Department of Chemical Sciences, School of Applied Sciences, University of Huddersfield, Queensgate, Huddersfield, HDI 3DH, UK

${ }^{*+}$ Orlando.DeAzevedo@hud.ac.uk

${ }^{*}$ M.Heron@hud.ac.uk

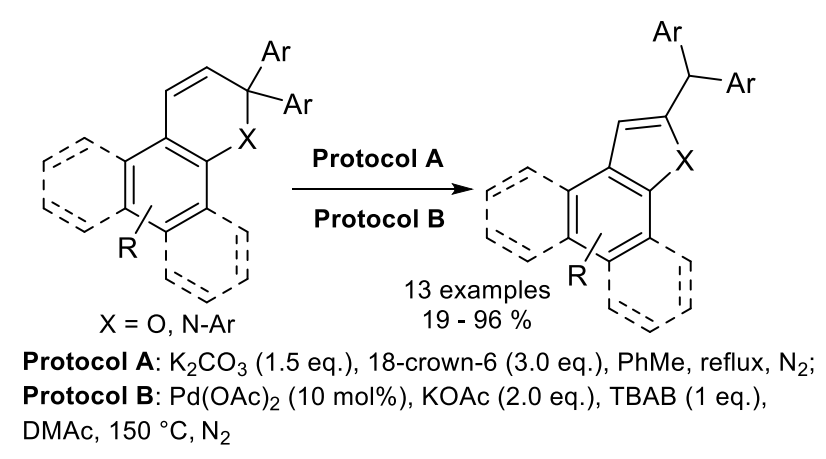

Abstract - A study of the ring-contraction of a model $3 H$-naphtho[2,1- $b]$ pyran is described in order to elucidate and optimise the ring-contraction of naphthopyrans. Two efficient basemediated protocols to access multiple naphthofurans, naphthodifurans and a benzo-fused indole in generally good yields are reported. Furthermore, a protocol to selectively prepare (hetero)aryl substituted naphthofurans via a Suzuki-coupling - ring-contraction process is presented. An additional protocol that allows Suzuki cross-coupling reactions to be performed on bromo-substituted naphthopyrans without the ring-contraction side reaction is reported. 
Keywords: Ring-Contraction, Phase-Transfer Catalysis, Naphthofuran, Naphthodifuran,

Benzindole.

\section{Introduction}

Naphthofurans are an important class of oxygen-containing heterocycle, consisting of a naphthalene moiety fused to a furan ring that occur naturally ${ }^{1}$ and exhibit a wide range of biological activities (Figure 1). ${ }^{2}$
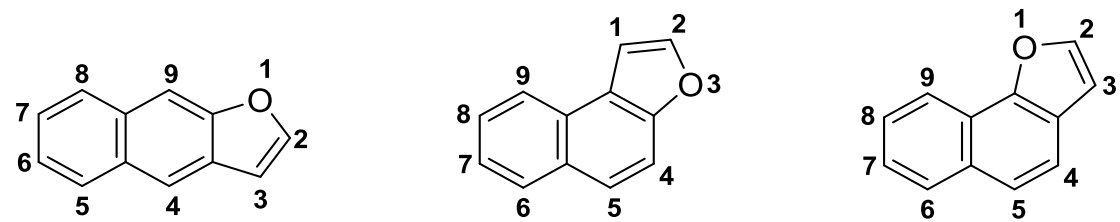

Naphtho[2,3-b]furan 1 Naphtho[2,1-b]furan 2 Naphtho[1,2-b]furan 3

\section{Figure 1. Isomeric naphthofurans}

Several naphtho[2,1-b]furans have shown genotoxic activity against different bacteria, ${ }^{3}$ cytotoxicity $^{4,5}$ and antiandrogen activity ${ }^{6}$ against human cancer lines, and more recently inhibition of the influenza A (H1N1) virus. ${ }^{7}$ Nitro-substituted naphtho[2,1-b]furans induce carcinogenic $^{8}$ and regulatory ${ }^{9}$ effects in mammalian cells. A naphtho[2,3-b]furan-4,9-dione has shown the ability to suppress keratinocyte hyperproliferation. ${ }^{10}$

Naphthodifuran derivatives have garnered interest in the materials arena, ${ }^{11}$ with a naphtho[1,2$\left.b: 5,6-b^{\prime}\right]$ difuran based oligomer offering potential in photovoltaic applications, ${ }^{12}$ and naphtho[2,1-b:4,3-b']difurans being employed in organic light emitting diodes and in organic field-effect transistors. ${ }^{13}$ Naphtho[2,1-b:6,5-b]difurans have been integrated in electronic inks in combination with organic semiconductors. ${ }^{14}$ 
Considering the extensive panoply of interesting properties that naphthofurans and naphthodifurans possess, it is extremely important to develop efficient methods for building naphtho(di)furan scaffolds. Recent syntheses of naphthodifurans have capitalised upon the cyclisation of $o$-hydroxyaryl substituted internal alkynes, ${ }^{15} \mathrm{Pd}$-mediated cyclisation of $o$-allyl hydroxynaphthalenes ${ }^{16}$ and a Pummerer annulation - cross-coupling strategy applied to ketene dithioacetal monoxide with hydroxynaphthalenes. ${ }^{17}$

A potential strategy for the synthesis of naphthofurans involves the ring-contraction of readily accessible naphthopyran systems. ${ }^{18}$ The ring-contraction of benzopyrans and naphthopyrans has been described almost invariably as unique serendipitous observations. For example, the oxidative ring-contraction of the 1,2-dihydrospiro[benzo[f]chroman-3,9'-xanthene] 4 afforded the 9-(naphtho[2,1-b]furan-2-yl)-9H-xanthene 5 in $34-57 \%$ yield upon thermolysis with sulfur (Scheme 1). ${ }^{19}$<smiles>[R]C1CC2(Oc3ccccc3O2)Oc2ccc3ccccc3c21</smiles>

4

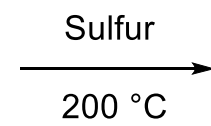

$$
\mathrm{R}=\mathrm{H} \text {, methyl, phenyl, tolyl }
$$

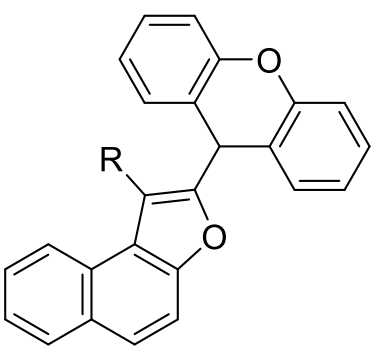

$534-57 \%$

\section{Scheme 1. Thermal ring-contraction of 1,2-dihydrospiro[benzo[f]chroman-3,9'- xanthene] 4}

The action of base on the 3-bromo substituted $2 H$-naphtho[1,2- $b]$ pyran 6 promoted an addition

- dehydrobromination reaction leading to the corresponding naphtho[1,2-b]furan 7 (Scheme 2). ${ }^{20}$ Conversely, heating aryl substituted naphthopyrans with 4-TsOH (20 mol \%) effects the 
destruction of the pyran ring via a ring-opening and Friedel-Crafts alkylation to afford inden3-yl-naphthols. ${ }^{21}$<smiles>COC(=O)c1c2c(c3ccccc3c1O)OC(C)(C)C(Br)=C2</smiles>

6

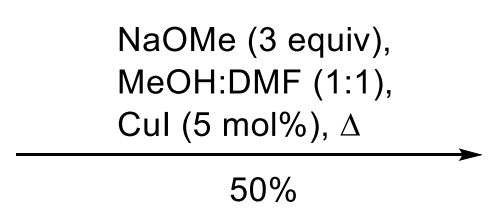

$50 \%$<smiles>C=C(C)c1cc2c(C(C)=O)c(O)c3ccccc3c2o1</smiles>

7

Scheme 2. Base mediated ring-contraction of 3-bromonaphthopyran 6

According to Gabbutt et al., the presence of very strong electron-withdrawing groups at the saturated carbon of the pyran moiety favours the quantitative ring-contraction of the spiro $3 \mathrm{H}$ naphtho[2,1-b]pyran-3,9'-thioxanthene-10,10-dioxide) 8 to generate the 9-(naphtho[2,1b]furan-2-yl)-9H-thioxanthene-10,10-dioxide 9 (Scheme 3). The bis-sulfone 10 underwent an efficient photochemical ring-contraction to the naphtho[2,1-b]furan 11 in $85 \%$ yield. ${ }^{22}$<smiles>O=S1(=O)c2ccccc2C2(C=Cc3c(ccc4ccccc34)O2)c2ccccc21</smiles>

8<smiles>CO[SH](=O)(OC)c1ccc(C2(c3ccc(S(C)(=O)=O)cc3)C=Cc3c(ccc4ccccc34)O2)cc1</smiles>

10<smiles></smiles>

$9100 \%$<smiles>COS(=O)(=O)c1ccc(C(c2ccc(S(C)(=O)=O)cc2)c2cc3c(ccc4ccccc43)o2)cc1</smiles>

$1185 \%$ 
The synthesis of benzo- and naphtho- fused pyrans and furans may often be intertwined, for example Banwell et al., have reported that the $\mathrm{Au}(\mathrm{I})$-catalysed intramolecular hydroarylation reaction of terminal alkynes $\mathbf{1 2 a}, \mathbf{b}$ affords mixtures of benzopyrans $(\mathbf{1 3}, \mathbf{1 5})$ and benzofurans $(\mathbf{1 4}, \mathbf{1 6})$ in near equal amounts (Scheme 4). ${ }^{23}$ According to the authors, the fragmentation of a late-stage aurylated intermediate generates the benzo- and naphtho- furans.<smiles>C#CCOc1ccccc1[N+](=O)[O-]</smiles>

$12 \mathrm{a}$<smiles>C#CCOc1ccc2ccccc2c1</smiles>

$12 b$
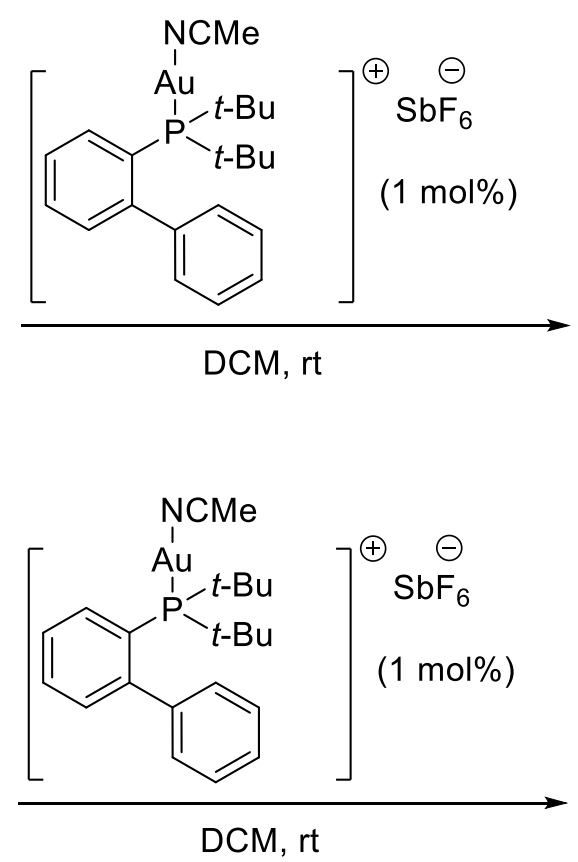

DCM, rt<smiles>C1=Cc2c(ccc3ccccc23)OC1</smiles>

$1541 \%$<smiles>Cc1cc2c(ccc3ccccc32)o1</smiles>

$1631 \%$

\section{Scheme 4. Au(I)-catalysed intramolecular hydroarylation of propargyl ethers to afford benzopyrans and benzofurans}

In an attempt to prepare a 6-styryl-2H[1]benzopyran from the 6-bromo-2,2-diaryl- $2 \mathrm{H}$ -

[1]benzopyran 17 and styrene, Gabbutt et al., instead isolated the 2-(diarylmethyl)-5styrylbenzofuran $\mathbf{1 8}$ in $30 \%$ yield resulting from a tandem Heck-coupling - ring-contraction sequence (Scheme 5). ${ }^{24}$ 
<smiles>Brc1ccc2c(c1)C=CC(Br)(Br)O2</smiles>

17

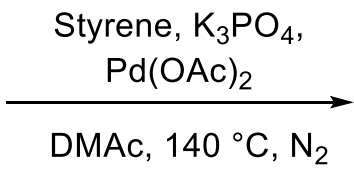

$\mathrm{Ar}=4-\mathrm{MeOC}_{6} \mathrm{H}_{4}$<smiles>BrC(Br)c1cc2cc(/C=C/c3ccccc3)ccc2o1</smiles>

$1830 \%$

\section{Scheme 5. Heck-coupling - ring-contraction of bromobenzopyran 17}

An undesirable ring-contraction of the $3 H$-naphtho[2,1- $b]$ pyran 19 to afford the naphtho[2,1b] furan 20 in $65 \%$ yield was observed instead of the postulated palladium-catalysed cyanation reaction (Scheme 6). ${ }^{25}$<smiles>CC(=O)c1ccc2c3c(ccc2c1)OC(Br)(C(C)(Br)Br)C(Br)=C3</smiles>

19

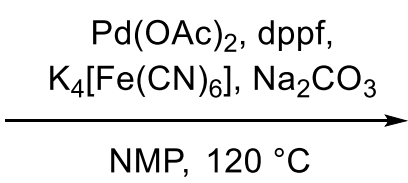

$\mathrm{Ar}=p-\mathrm{FC}_{6} \mathrm{H}_{4}$<smiles>CC(=O)c1ccc2c(ccc3oc(C(Br)Br)cc32)c1</smiles>

$2065 \%$

\section{Scheme 6. Failed Pd-mediated cyanation of 2-bromonaphthopyran 19}

Given the predisposition of the pyran unit to contract under a variety of reaction conditions, especially including in the presence of base and palladium, this present study aims to understand the ring-contraction mechanism of naphthopyrans. Furthermore, our investigations have revealed two efficient and robust ring-contraction protocols which have been successfully applied to the preparation of naphthofurans, naphthodifurans and a benzindole. Moreover, specific reaction conditions to effect either a Suzuki-coupling - ring-contraction or a selective Suzuki-coupling without ring-contraction, are described. The foregoing reaction conditions constitute the first effective protocol to selectively prepare naphthofurans via a sequential process. 


\section{Results and Discussion}

Since ring-contraction may occur in pyran systems during palladium-promoted cross-coupling reactions, a kinetic study was developed to gather more information about the ring-contraction process and determine the ideal experimental conditions to effect the ring-contraction. The ring-contraction of 3,3-bis(4-methoxyphenyl)-3H-naphtho[2,1-b]pyran 21 to naphtho[2,1b]furan 22 under different experimental conditions was analysed (Scheme 7).<smiles>BrC1(Br)C=Cc2c(ccc3ccccc23)O1</smiles>

21
Ring-Contraction

$$
\mathrm{Ar}=4-\mathrm{MeOC}_{6} \mathrm{H}_{4}
$$<smiles>BrC(Br)c1cc2c(ccc3ccccc32)o1</smiles>

22

\section{Scheme 7. Ring-contraction of 3,3-bis(4-methoxyphenyl)-3H-naphtho[2,1-b]pyran 21}

First, a series of test reactions were performed in order to evaluate the overall stability of the naphthopyran 21 to various solvents and reactants. Thus, there was no ring-contraction after exposure of 21 to either DCM, PhMe, EtOH, DMAc or mixtures of PhMe:EtOH (1:1) at room temperature (rt) or reflux (Entries $1-5$, Table 1). Additionally there was no ring-contraction when 21 was exposed to DCM with $\mathrm{Pd}\left(\mathrm{PPh}_{3}\right)_{4}(5 \mathrm{~mol} \%)$ at rt (Entry 6, Table 1).

Table 1. Evaluation of the behavior of naphthopyran 21 to reactants and solvents

\begin{tabular}{|c|c|c|c|c|c|c|c|}
\hline Entry & $\begin{array}{l}\text { Pd } \\
\text { ataly }\end{array}$ & Base & Solvent & Temp. $/{ }^{\circ} \mathrm{C}$ & Time / h & $21: 22^{+}$ & k /M.h' \\
\hline 1 & No & No & DCM & $\mathrm{rt}$ & 18 & $1.0: 0$ & 0 \\
\hline 2 & No & No & PhMe & $\mathrm{rt}$ & 17 & $1.0: 0$ & 0 \\
\hline 3 & No & No & EtOH & $\mathrm{rt}$ & 28 & $1.0: 0$ & 0 \\
\hline \multirow[t]{2}{*}{4} & No & No & PhMe:EtOH & rt and/or & $15(\mathrm{rt})$ & $1.0: 0$ & 0 \\
\hline & & & $(1: 1)$ & reflux & 14 (reflux) & $1.0: 0$ & 0 \\
\hline
\end{tabular}


Table 1. Evaluation of the behavior of naphthopyran 21 to reactants and solvents

(Continuation)

\begin{tabular}{|c|c|c|c|c|c|c|c|}
\hline Entry & Pd Catalyst & Base & Solvent & Temp. $/{ }^{\circ} \mathrm{C}$ & Time / h & $21: 22^{+}$ & k /M.h. \\
\hline \multirow[t]{2}{*}{5} & No & No & DMAc & $\mathrm{rt}$ and/or & $28(\mathrm{rt})$ & $1.0: 0$ & 0 \\
\hline & & & & 150 & $14\left(150^{\circ} \mathrm{C}\right)$ & $1.0: 0$ & 0 \\
\hline \multirow[t]{2}{*}{6} & $\mathrm{Pd}\left(\mathrm{PPh}_{3}\right)_{4}$ & No & DCM & $\mathrm{rt}$ & 23 & $1.0: 0$ & 0 \\
\hline & $(5 \mathrm{~mol} \%)$ & & & & & & \\
\hline \multirow[t]{2}{*}{$7 *$} & $\mathrm{Pd}\left(\mathrm{PPh}_{3}\right)_{4}$ & $\mathrm{~K}_{2} \mathrm{CO}_{3}$ & PhMe:EtOH & reflux & 80 & $1.0: 3.5$ & 0.48 \\
\hline & $(5 \mathrm{~mol} \%)$ & ( 1.5 equiv) & $(1: 1)$ & & & & \\
\hline \multirow[t]{2}{*}{$8^{¥}$} & $\mathrm{Pd}(\mathrm{OAc})_{2}$ & KOAc & DMAc & 150 & 5 & 1.0:1.1 & N/A \\
\hline & $(10 \mathrm{~mol} \%)$ & (1.9 equiv) & & & & & \\
\hline \multirow[t]{2}{*}{9 "\# } & No & $\mathrm{K}_{2} \mathrm{CO}_{3}$ & PhMe:EtOH & reflux & 80 & $1.0: 2.0$ & 0.44 \\
\hline & & (1.5 equiv) & $(1: 1)$ & & & & \\
\hline \multirow[t]{2}{*}{10} & No & $\mathrm{K}_{2} \mathrm{CO}_{3}$ & PhMe:EtOH & reflux & 74 & $0: 1.0$ & 0.62 \\
\hline & & (3.0 equiv) & $(1: 1)$ & & & & \\
\hline \multirow[t]{2}{*}{11} & $\mathrm{Pd}\left(\mathrm{PPh}_{3}\right)_{4}$ & No & PhMe:EtOH & reflux & 48 & $1.0: 0$ & 0 \\
\hline & $(5 \mathrm{~mol} \%)$ & & $(1: 1)$ & & & & \\
\hline \multirow[t]{2}{*}{$12^{\#}$} & No & $\mathrm{Cs}_{2} \mathrm{CO}_{3}$ & PhMe:EtOH & reflux & 80 & $1.0: 2.0$ & 0.41 \\
\hline & & ( 1.5 equiv) & $(1: 1)$ & & & & \\
\hline \multirow[t]{2}{*}{$\mathbf{1 3}^{\#}$} & No & $\mathrm{Li}_{2} \mathrm{CO}_{3}$ & $\mathrm{PhMe}: \mathrm{EtOH}$ & reflux & 80 & $1.8: 1.0$ & 0.21 \\
\hline & & (1.5 equiv) & $(1: 1)$ & & & & \\
\hline \multirow[t]{2}{*}{$14^{\#}$} & No & $\mathrm{Na}_{2} \mathrm{CO}_{3}$ & PhMe:EtOH & reflux & 80 & $1.1: 1.0$ & 0.31 \\
\hline & & (1.5 equiv) & $(1: 1)$ & & & & \\
\hline \multirow[t]{2}{*}{$15^{¥}$} & No & $\mathrm{K}_{3} \mathrm{PO}_{4}$ & $\mathrm{PhMe}: \mathrm{EtOH}$ & reflux & 14 & $1.7: 1.0$ & N/A \\
\hline & & (1.5 equiv) & $(1: 1)$ & & & & \\
\hline
\end{tabular}

\footnotetext{
${ }^{\dagger}$ Relative proportion of $\mathbf{2 1 : 2 2}$ calculated based on the integral of the ${ }^{1} \mathrm{H}$ NMR spectrum of the reaction mixture.

$¥$ Rate constant data presented in Figure 3. " Rate constant data presented in Figure 2. ${ }^{¥}$ Relative proportion of 21:22 determined after reaction terminated; no kinetic data was recorded.
} 
Two typical Pd-mediated cross-coupling reaction conditions ${ }^{26}$ were employed to ring-contract $3 H$-naphtho[2,1-b]pyran 21 at a fairly slow rate. When using $\mathrm{K}_{2} \mathrm{CO}_{3}$ (1.5 equiv) and $\mathrm{Pd}\left(\mathrm{PPh}_{3}\right)_{4}$ (5 mol\%) in PhMe:EtOH (1:1) at reflux, a 1.0:3.5 (21:22) mixture was obtained after $80 \mathrm{~h}$ (Entry 7, Table 1). When using KOAc (1.9 equiv) and $\mathrm{Pd}(\mathrm{OAc})_{2}(10 \mathrm{~mol} \%)$ in DMAc at 150 ${ }^{\circ} \mathrm{C}$, a 1.0:1.1 (21:22) mixture was attained after $5 \mathrm{~h}$ (Entry 8, Table 1). Formation of the ringcontracted product 22 was determined by the presence in the ${ }^{1} \mathrm{H}$ NMR spectrum of a singlet at $6.76 \mathrm{ppm}$ and at $5.63 \mathrm{ppm}$ which corresponded to the resonance of $\mathrm{H}-1$ and $\mathrm{H}-\alpha$, respectively.

A surprising finding was that the ring-contraction of the $3 H$-naphtho[2,1- $b$ ]pyran 21 occurred with zero order kinetics without the deliberate addition of a palladium catalyst. Thus, when employing $\mathrm{K}_{2} \mathrm{CO}_{3}$ (1.5 equiv) in PhMe:EtOH (1:1) at reflux, a 1:2 (21:22) mixture was produced after $80 \mathrm{~h}$ (Entry 9, Table 1). Palladium cross-contamination from laboratory equipment was ruled out after obtaining the same outcome with a virgin stirrer bar, condenser and reaction flask (Entry 9, Table 1). ${ }^{27}$ On the other hand, considering the prior work from Leadbeater et al. ${ }^{28}$ it was determined by ICP-MS that $\mathrm{Li}_{2} \mathrm{CO}_{3}, \mathrm{Na}_{2} \mathrm{CO}_{3}, \mathrm{~K}_{2} \mathrm{CO}_{3}$ and $\mathrm{Cs}_{2} \mathrm{CO}_{3}$ (supplied by Alfa Aesar) contained extremely low levels of palladium $(0.35-2.65 \mathrm{ppb})$ - at the very limit of detection of these bases. Consequently, it was extremely unlikely that any significant palladium contamination had occurred and, therefore, it was safe to assume that the ring-contraction of the $3 H$-naphtho[2,1-b]pyran 21 did not require palladium to occur. Furthermore, it was determined that the rate of the ring-contraction of the $3 H$-naphtho[2,1b] pyran 21 depended on the stoichiometry of $\mathrm{K}_{2} \mathrm{CO}_{3}$ : by doubling the molar amount of $\mathrm{K}_{2} \mathrm{CO}_{3}$ (3 equiv), the rate constant of the reaction increased by $29 \%$ (Entry 10, Table 1). Thus, the ring-contraction of the 3H-naphtho[2,1-b]pyran 21 was complete after $74 \mathrm{~h}$ of reaction. Notably, in the absence of base, but employing $\mathrm{Pd}\left(\mathrm{PPh}_{3}\right)_{4}(5 \mathrm{~mol} \%)$ in $\mathrm{PhMe}: \mathrm{EtOH}(1: 1)$ at 
reflux, no ring-contraction of $\mathbf{2 1}$ was observed after $48 \mathrm{~h}$ of reaction, which strongly reaffirmed that the base played a pivotal role in the ring-contraction process (Entry 11, Table 1).

The kinetics of the ring-contraction of the $3 H$-naphtho[2,1-b]pyran 21 varied with the nature of the carbonate bases (Figure 2). A similar rate constant was observed between $\mathrm{Cs}_{2} \mathrm{CO}_{3}$ (Entry 12, Table 1) and $\mathrm{K}_{2} \mathrm{CO}_{3}$ (Entry 9, Table 1). On the other hand, when employing $\mathrm{Li}_{2} \mathrm{CO}_{3}$ (Entry 13, Table 1), the rate constant was two times smaller when compared to $\mathrm{K}_{2} \mathrm{CO}_{3}$. Hence, when using $\mathrm{Na}_{2} \mathrm{CO}_{3}$ (Entry 14, Table 1), the ring-contraction occurred faster than $\mathrm{Li}_{2} \mathrm{CO}_{3}$ yet slower than $\mathrm{K}_{2} \mathrm{CO}_{3}$ and $\mathrm{Cs}_{2} \mathrm{CO}_{3}-$ after $80 \mathrm{~h}$ only $48 \%$ of the $3 H$-naphtho[2,1- $b$ ]pyran 21 had ringcontracted. The differences in the kinetics of the ring-contraction of the $3 H$-naphtho[2,1b]pyran 21 by employing different carbonate bases could be attributed to differences in solubility in PhMe:EtOH $(1: 1)-\mathrm{Li}_{2} \mathrm{CO}_{3}$ is less soluble than $\mathrm{Na}_{2} \mathrm{CO}_{3}$ as lithium is a harder metal. Likewise, $\mathrm{Na}_{2} \mathrm{CO}_{3}$ is less soluble when compared to $\mathrm{K}_{2} \mathrm{CO}_{3}$ and $\mathrm{Cs}_{2} \mathrm{CO}_{3}$. 


\section{Rate Plot}

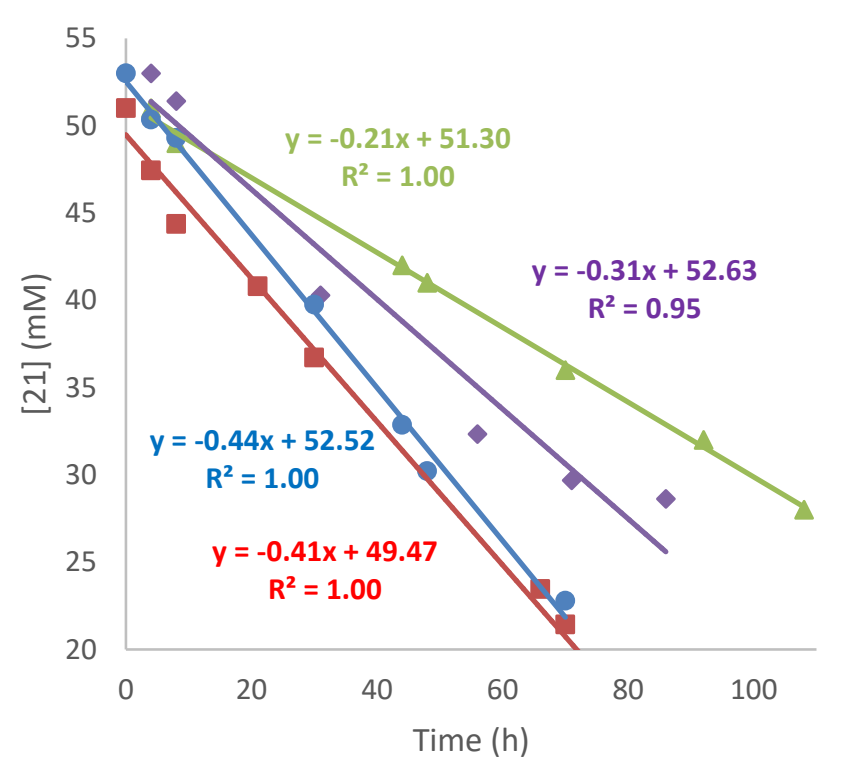

\footnotetext{
$\triangle \mathrm{Li}_{2} \mathrm{CO}_{3}$ (1.5 equiv), PhMe:EtOH (1:1), reflux (Entry 13, Table 1)

- $\mathrm{K}_{2} \mathrm{CO}_{3}$ (1.5 equiv), PhMe:EtOH (1:1), reflux (Entry 9, Table 1)

$\diamond \mathrm{Na}_{2} \mathrm{CO}_{3}$ (1.5 equiv), PhMe:EtOH (1:1), reflux (Entry 14, Table 1)

- $\mathrm{Cs}_{2} \mathrm{CO}_{3}$ (1.5 equiv), PhMe:EtOH (1:1), reflux (Entry 12, Table 1)
}

Figure 2. Rate Plots showing the influence of base upon the contraction of naphthopyran 21

Bases with varying $\mathrm{pKb}$ values were also tested: when using $\mathrm{K}_{3} \mathrm{PO}_{4}$ (1.5 equiv), which is a stronger base than $\mathrm{K}_{2} \mathrm{CO}_{3}$, in $\mathrm{PhMe}: \mathrm{EtOH}(1: 1)$ at reflux, $37 \%$ of the $3 H$-naphtho[2,1-b]pyran 21 had ring-contracted after $14 \mathrm{~h}$ of reaction (Entry 15, Table 1). By comparison, when employing $\mathrm{K}_{2} \mathrm{CO}_{3}$, only $13 \%$ of the ring-contracted product 22 was formed after $14 \mathrm{~h}$. Therefore, the ring-contraction of the $3 H$-naphtho[2,1-b]pyran 21 when using the stronger base $\mathrm{K}_{3} \mathrm{PO}_{4}$ was $35 \%$ faster than $\mathrm{K}_{2} \mathrm{CO}_{3}$. An obvious problem concerning the ring-contraction of 21 was the relatively low rate of the reaction (Entry 1, Table 2). Consequently, the effect of 18crown-6 was tested as it could act as a phase-transfer catalyst. ${ }^{29}$ Thus, with 18 -crown-6 (3 equiv) and $\mathrm{K}_{2} \mathrm{CO}_{3}$ (1.5 equiv) in toluene at reflux, the rate constant of the ring-contraction increased by one order of magnitude (Entry 2, Table 2). Consequently, in the presence of 18crown-6, the $3 H$-naphtho[2,1-b]pyran 21 fully ring-contracted to the naphtho[2,1-b]furan 22 
with zero-order kinetics after only $10 \mathrm{~h}$ (Figure 3). No ring-contraction was observed in the absence of $\mathrm{K}_{2} \mathrm{CO}_{3}$ (Entry 3, Table 2). Another important finding was that ring-contraction of 21 occurred even with only $10 \mathrm{~mol} \%$ of $\mathrm{K}_{2} \mathrm{CO}_{3}$, with 18 -crown-6 $(20 \mathrm{~mol} \%)$ in toluene at reflux (Figure 3 and Entry 4, Table 2). Thus, the 3H-naphtho[2,1-b]pyran 21 fully ring-contracted to the naphtho[2,1-b]furan 22 after approximately 24 h. This result showed that the base, already established as pivotal for the ring-contraction process, was not consumed in the reaction and was instead being regenerated in a catalytic fashion.

Table 2. Influence of base, crown ether and Pd-catalyst on ring-contraction of naphthopyran 21

\begin{tabular}{|c|c|c|c|c|c|c|}
\hline Entry & Base & Pd Catalyst & crown Ether & Solvent & Temp. & k/ M.h'-1 \\
\hline $1^{* \#}$ & $\begin{array}{c}\mathrm{K}_{2} \mathrm{CO}_{3}(1.5 \\
\text { equiv) }\end{array}$ & No & No & $\mathrm{PhMe}$ & reflux & 0.44 \\
\hline 2 & $\begin{array}{c}\mathrm{K}_{2} \mathrm{CO}_{3}(1.5 \\
\text { equiv) }\end{array}$ & No & $\begin{array}{c}\text { 18-crown-6 (3.0 } \\
\text { equiv) }\end{array}$ & $\mathrm{PhMe}$ & reflux & 5.4 \\
\hline 3 & No & No & $\begin{array}{c}\text { 18-crown-6 (3.0 } \\
\text { equiv) }\end{array}$ & $\mathrm{PhMe}$ & reflux & 0 \\
\hline 4 & $\begin{array}{c}\mathrm{K}_{2} \mathrm{CO}_{3}(10 \\
\mathrm{mol} \%)\end{array}$ & No & $\begin{array}{c}\text { 18-crown-6 (20 } \\
\text { mol\%) }\end{array}$ & $\mathrm{PhMe}$ & reflux & 1.6 \\
\hline 5 & $\begin{array}{c}\mathrm{K}_{2} \mathrm{CO}_{3}(1.5 \\
\text { equiv })\end{array}$ & $\begin{array}{l}\mathrm{Pd}(\mathrm{OAc})_{2} \\
(4 \mathrm{~mol} \%)\end{array}$ & $\begin{array}{c}\text { 18-crown-6 (3.0 } \\
\text { equiv) }\end{array}$ & $\mathrm{PhMe}$ & reflux & 8.3 \\
\hline
\end{tabular}

\footnotetext{
${ }^{\ddagger}$ Rate constant data presented in Figure 3. ${ }^{\#}$ Rate constant data presented in Figure 2.
} 


\section{Rate Plot}

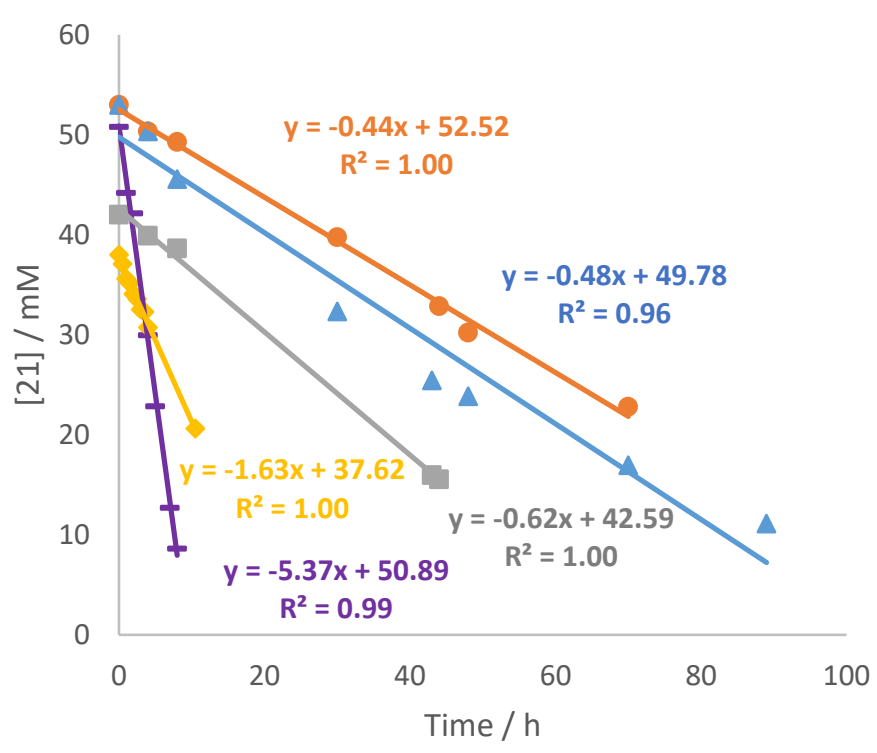

\footnotetext{
- $\mathrm{K}_{2} \mathrm{CO}_{3}$ (1.5 equiv), PhMe:EtOH (1:1), reflux (Entry 9, Table 1)

- $\mathrm{K}_{2} \mathrm{CO}_{3}$ (3 equiv), PhMe:EtOH (1:1), reflux (Entry 10, Table 1)

- $\mathrm{K}_{2} \mathrm{CO}_{3}$ (1.5 equiv), 18-crown-6 (3.0 equiv), PhMe, reflux

(Entry 2, Table 2)
}

$\Delta \mathrm{Pd}\left(\mathrm{PPh}_{3}\right)_{4} \quad(5 \quad \mathrm{~mol} \%), \quad \mathrm{K}_{2} \mathrm{CO}_{3} \quad(1.5$ equiv $)$, PhMe:EtOH (1:1), reflux (Entry 7, Table 1)

$\mathrm{K}_{2} \mathrm{CO}_{3}(10 \mathrm{~mol} \%), 18$-crown-6 (20 mol\%), PhMe, reflux (Entry 4, Table 2)

\section{Figure 3. Rate Plot showing influence of base and crown ether concentration on rate of ring-contraction of naphthopyran 21}

Since the ring-contraction of $3 H$-naphtho[2,1-b]pyran $\mathbf{2 1}$ follows zero-order kinetics and operates under catalytic amounts of base, a mechanism for the ring-contraction of the $3 \mathrm{H}$ naphtho[2,1-b]pyran 21 was proposed. An initial thermal $6 \pi$-electrocyclic ring-opening of the pyran unit of $\mathbf{2 1}$ led to the formation of the dienone, ${ }^{30}$ this feature is supported by the reaction mixture taking on an intense orange hue upon heating (Scheme 8). It was rationalized that the non-solvated 'naked' carbonate anion would abstract a proton from $\mathbf{2 3}$ to generate the allenoate 24. Considering previous reports of base mediated ring-closure of allenylphenols to benzofurans, ${ }^{31}$ it was proposed that the 5-exo-dig cyclization of the allenoate $\mathbf{2 4}$ led to the formation of the naphtho[2,1-b]furan 22 with regeneration of the base. 


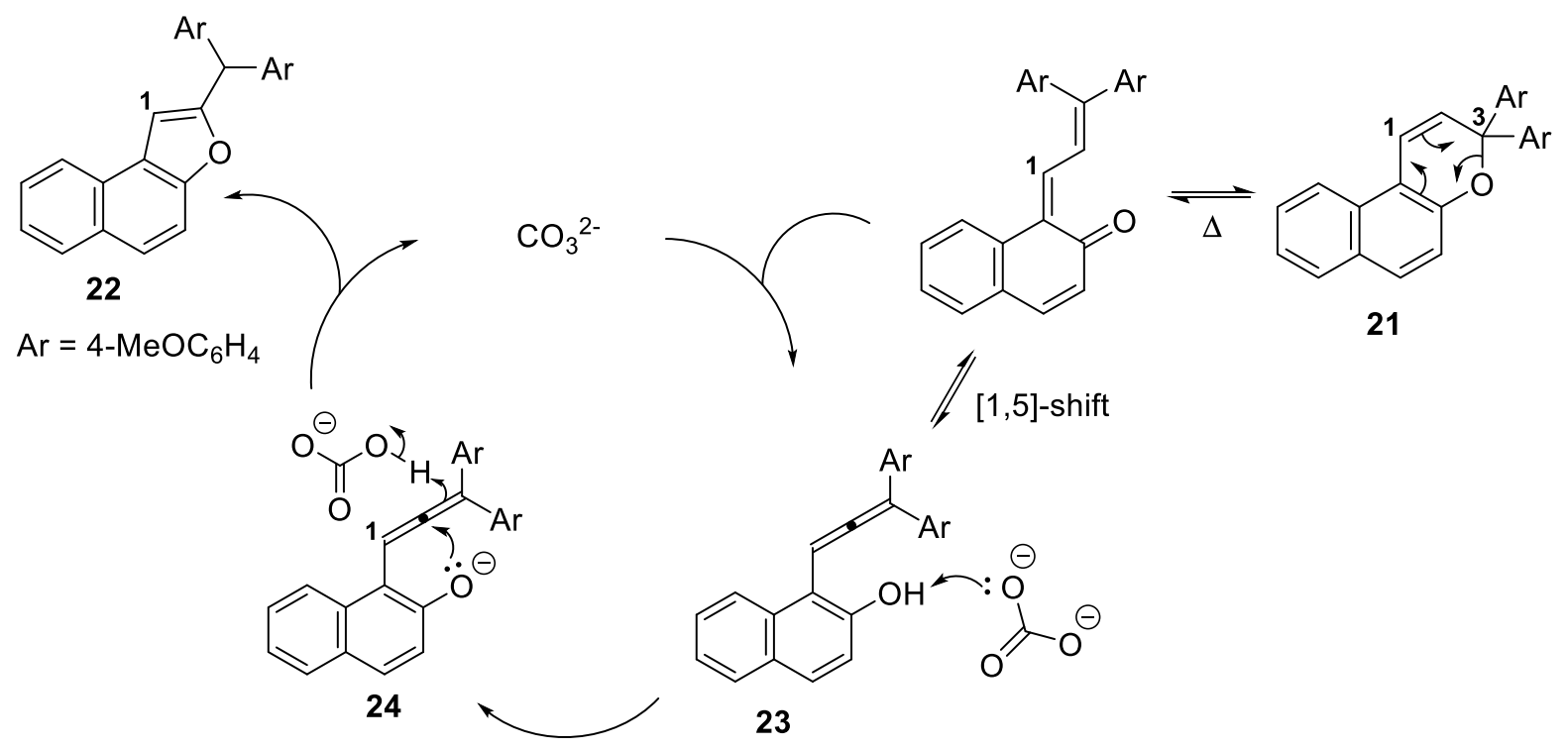

Scheme 8. Proposed base-mediated mechanism for the ring-contraction of naphthopyran 21

Moreover, the influence of the palladium catalyst on the rate of the ring-contraction was also tested. Curiously, when employing $\mathrm{Pd}(\mathrm{OAc})_{2}$ (4 mol\%), 18-crown-6 (3 equiv) and $\mathrm{K}_{2} \mathrm{CO}_{3}(1.5$ equiv) in toluene at reflux (Entry 5, Table 2 and Figure 4), the rate constant of the ringcontraction of $\mathbf{2 1}$ increased by 35\%. This increased rate of the reaction implies that a parallel mechanism mediated by nanoparticulate palladium ${ }^{32}$ takes place. The oxidative addition of nanoparticulate $\mathrm{Pd}^{0}$ to $\mathrm{C}-1$ led to the formation of the $\pi$-allyl complex 25 which reorganises to palladacycle 26 (Scheme 9). Hence, the reductive elimination promoted by the base afforded 24 and regenerated the nanoparticulate $\mathrm{Pd}^{0}$. In a final step, the 5-exo-dig cyclization of 24 led to the formation of the naphtho[2,1-b]furan 22 with regeneration of the base. 


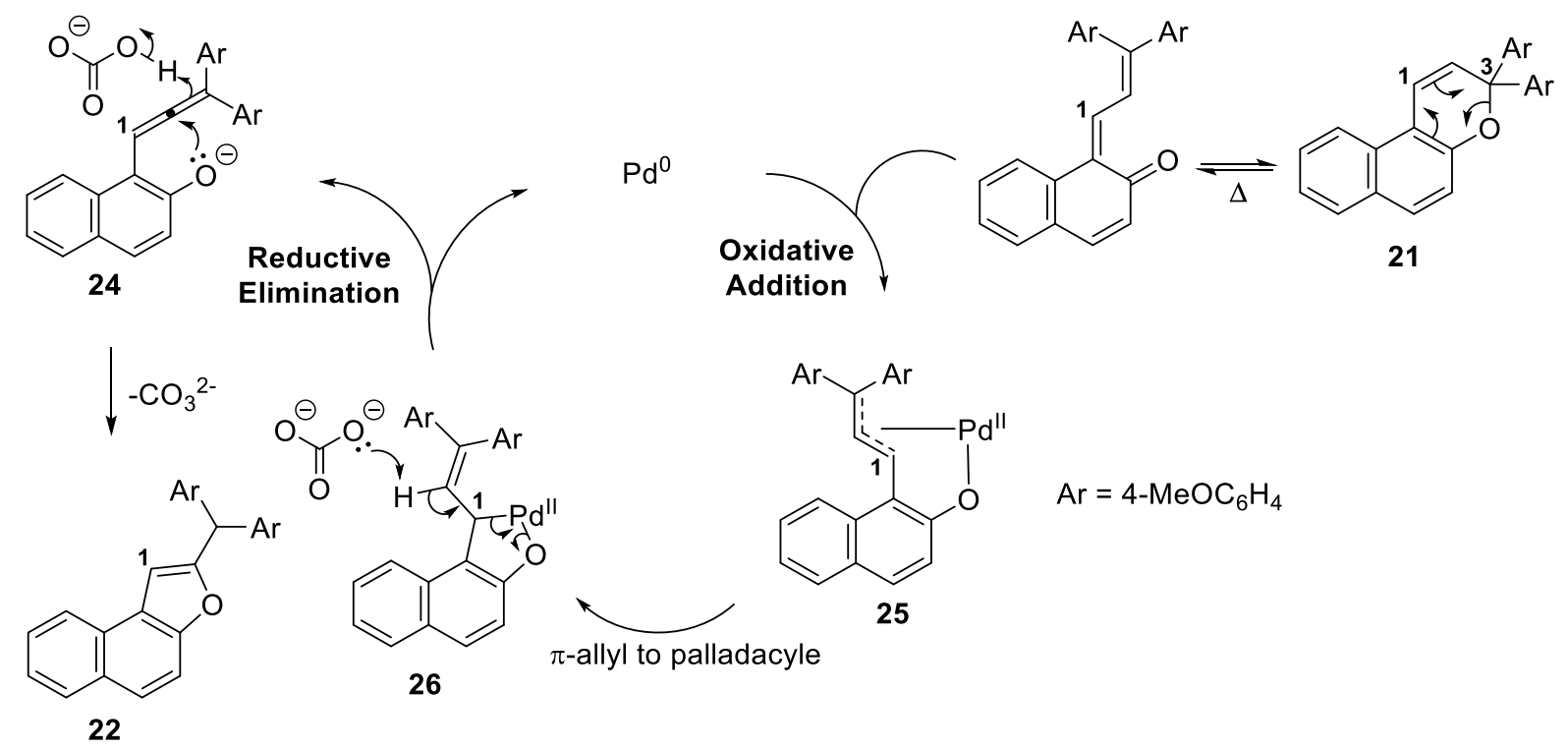

Scheme 9. Proposed mechanism for the ring-contraction of naphthopyran 21 involving base and Pd-catalyst

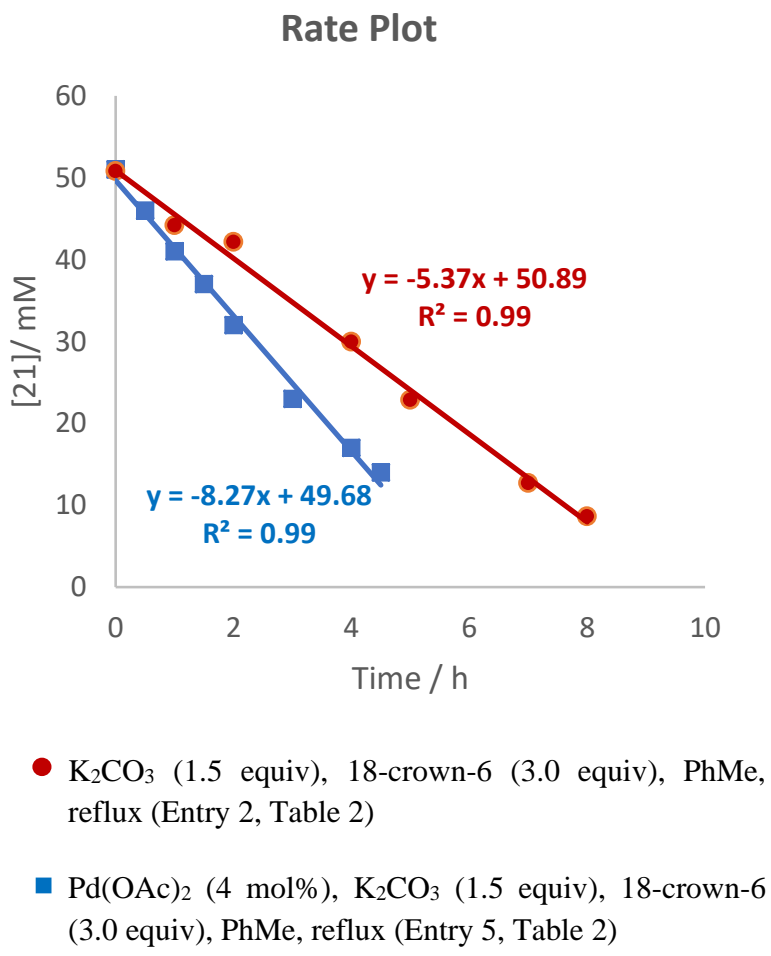

Figure 4. Comparative rate plots for the ring-contraction of naphthopyran 21 with and without Pd-catalyst 
As a result of this study, an experimental protocol (Protocol A) was developed that allowed the complete efficient ring-contraction of $3 H$-naphtho[2,1-b]pyran 21 under $9 \mathrm{~h}$ of reaction in the absence of palladium, giving the naphtho[2,1-b]furan 22 in $80 \%$ yield after a simple crystallization from DCM/ hexane (Scheme 10).<smiles>BrC1(Br)C=Cc2c(ccc3ccccc23)O1</smiles>

21
Protocol A: $\mathrm{K}_{2} \mathrm{CO}_{3}$ (1.5 equiv), 18-crown-6 (3 equiv), PhMe, reflux, $9 \mathrm{~h}, \mathrm{~N}_{2}$<smiles>BrC(Br)c1cc2c(ccc3ccccc32)o1</smiles>

$2280 \%$

$\mathrm{Ar}=4-\mathrm{MeOC}_{6} \mathrm{H}_{4}$

\section{Scheme 10. Optimised Pd-free reagent conditions for the ring-contraction of naphthopyran 21 (Protocol A)}

Considering the dramatic effect of the crown ether on the rate of the reaction, the use of the comparatively cheaper tetrabutylammonium bromide (TBAB) was also tested. Thus, by using $\mathrm{Pd}(\mathrm{OAc})_{2}(10 \mathrm{~mol} \%), \mathrm{KOAc}\left(1.9\right.$ equiv), $\mathrm{TBAB}\left(1\right.$ equiv) in DMAc at $150{ }^{\circ} \mathrm{C}$, the naphtho[2,1b]furan 22 was formed as the only product after only $6 \mathrm{~h}$ and isolated in $78 \%$ yield albeit after column chromatography (Scheme 11). Thus, TBAB constituted an alternative to 18-crown-6 for the ring-contraction process (Protocol B). The addition of a catalytic amount of $\mathrm{Pd}(\mathrm{OAc})_{2}$ was justified by the previously demonstrated enhancement of the rate of the reaction. Furthermore, the use of DMAc allowed the reactions to be performed at a higher temperature than toluene which also contributed to the enhanced kinetics. 
<smiles>BrC1(Br)C=Cc2c(ccc3ccccc23)O1</smiles>

21
Protocol B: $\mathrm{Pd}(\mathrm{OAc})_{2}$

$(10 \mathrm{~mol} \%)$

KOAc ( 1.9 equiv),

TBAB (1 equiv),

DMAc, $150{ }^{\circ} \mathrm{C}, 6 \mathrm{~h}, \mathrm{~N}_{2}$<smiles>BrC(Br)c1cc2c(ccc3ccccc32)o1</smiles>

$2278 \%$

$\mathrm{Ar}=4-\mathrm{MeOC}_{6} \mathrm{H}_{4}$

Scheme 11. Optimised ring-contraction conditions for naphthopyran 21 in the presence of the Pd-catalyst (Protocol B)

To extend the scope of the ring-contraction to more complex systems and establish a comparison between Protocols A and B, a variety of substrates that were to hand were subjected to both the ring-contraction protocols (Scheme 12 and Table 3).

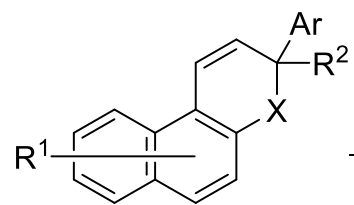

27
Protocol A and B

8-crown-6 $(3.0$

Protocol A: $\mathrm{K}_{2} \mathrm{CO}_{3}(1.5$
equiv), PhMe, reflux, $\mathrm{N}_{2}$

Protocol B: $\mathrm{Pd}(\mathrm{OAc})_{2}(10 \mathrm{~mol} \%)$, KOAc (2.0 equiv), TBAB (1 equiv), DMAc, $150{ }^{\circ} \mathrm{C}, \mathrm{N}_{2}$

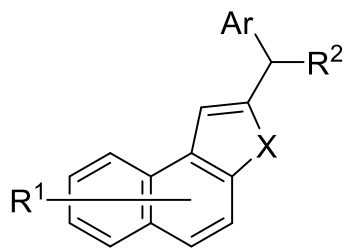

28

Scheme 12. Reagents and conditions for the optimised protocols for the ringcontraction of substituted $3 H$-naphtho[2,1-b]pyrans and a benzo-fused dihydroquinoline 
Table 3. Selected examples of the ring-contraction of substituted $3 H$-naphtho[2,1$b$ ]pyrans, naphthodipyrans and a benzo-fused dihydroquinoline $\left(\mathrm{Ar}=4-\mathrm{MeOC}_{6} \mathrm{H}_{4}\right)$

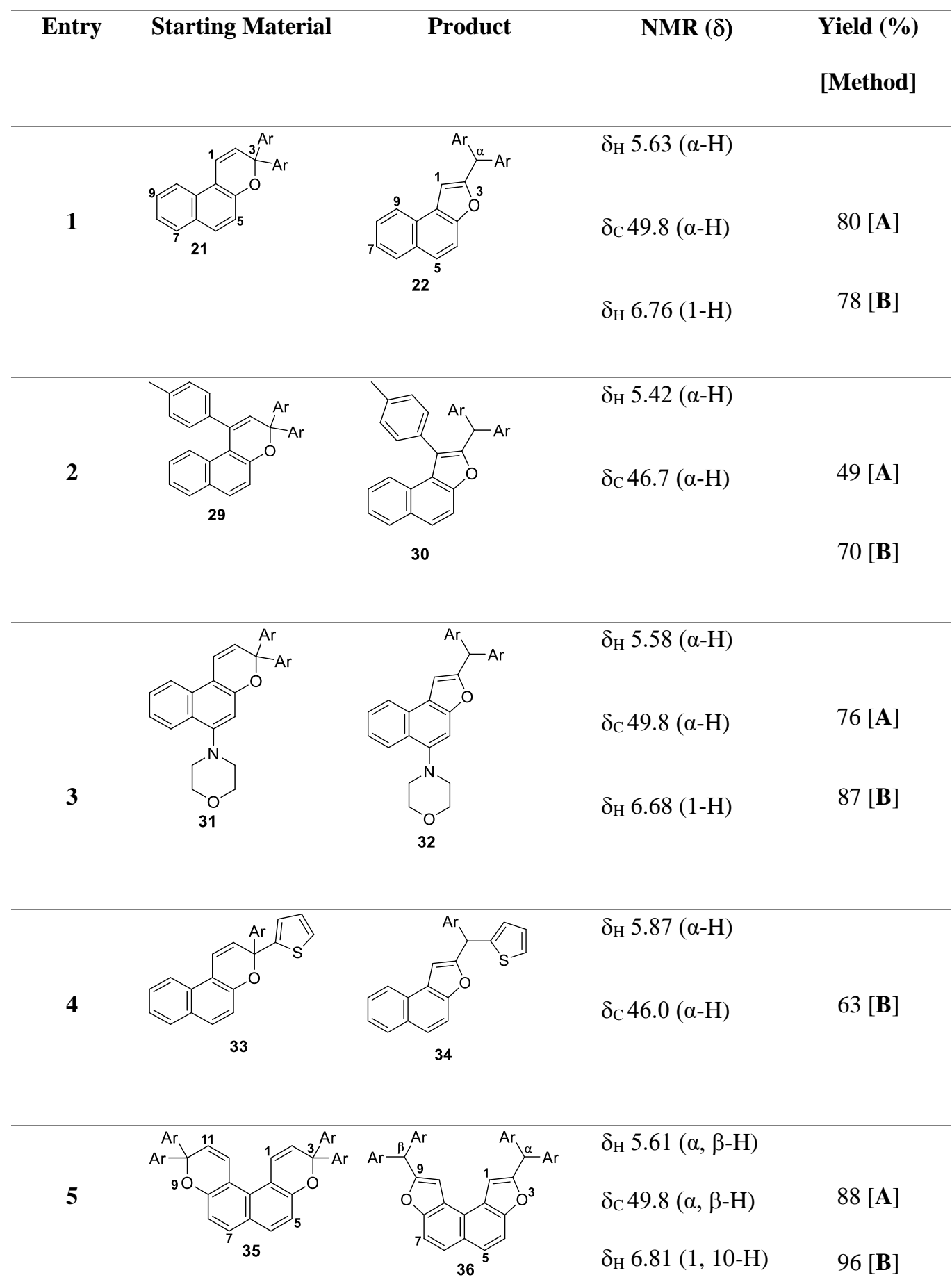


Table 3. Selected examples of the ring-contraction of substituted $3 H$-naphtho[2,1b]pyrans, naphthodipyrans and a benzo-fused dihydroquinoline (Continuation) (Ar $\left.=4-\mathrm{MeOC}_{6} \mathrm{H}_{4}\right)$

\begin{tabular}{|c|c|c|c|c|}
\hline Entry & $\begin{array}{l}\text { Starting } \\
\text { Material }\end{array}$ & Product & NMR ( $\delta)$ & $\begin{array}{l}\text { Yield }(\%) \\
\text { [Method] }\end{array}$ \\
\hline 6 & 37 & & $\begin{array}{l}\delta_{\mathrm{H}} 5.60(\alpha, \beta-\mathrm{H}) \\
\delta_{\mathrm{C}} 49.8(\alpha, \beta-\mathrm{H}) \\
\delta_{\mathrm{H}} 6.75(1,6-\mathrm{H})\end{array}$ & $\begin{array}{l}48[\mathbf{A}] \\
22[\mathbf{B}]\end{array}$ \\
\hline 7 & 39 & 40 & $\begin{array}{l}\delta_{\mathrm{H}} 5.73(\alpha, \beta-\mathrm{H}) \\
\delta_{\mathrm{C}} 49.2(\alpha, \beta-\mathrm{H}) \\
\delta_{\mathrm{H}} 6.68(1,6-\mathrm{H})\end{array}$ & $74[\mathbf{A}]$ \\
\hline 8 & 41 & 42 & $\begin{array}{l}\delta_{\mathrm{H}} 5.27(\alpha-\mathrm{H}) \\
\delta_{\mathrm{C}} 48.1(\alpha-\mathrm{H}) \\
\delta_{\mathrm{H}} 6.56(1-\mathrm{H})\end{array}$ & $80[\mathbf{A}]$ \\
\hline
\end{tabular}

Protocols $\mathbf{A}$ and $\mathbf{B}$ were successfully applied to the electron-rich $3 H$-naphtho[2,1-b]pyran $\mathbf{3 1}$, containing an electron-donating morpholino group at C-6, giving the corresponding naphtho[2,1-b]furan 32 (Entry 3, Table 3) in good yield (76\%, Protocol A) and very good yield (87\%, Protocol B). Furthermore, Protocol B was also effectively applied to the ringcontraction of 3H-naphtho[2,1-b]pyran 33 (Entry 4, Table 3), containing the electron-donating thienyl group at C-3, giving the naphtho[2,1-b]furan $\mathbf{3 4}$ in $63 \%$ yield. As stated before, both 
Protocols A and $\mathbf{B}$ were employed to the more electronically neutral $3 H$-naphtho[2,1-b]pyran 21 (Entry 1, Table 3) in similar yield (78 - 80\%). Moreover, both procedures (A and B) were used to ring-contract bisnaphthopyrans 35 (Entry 5, Table 3) and 37 (Entry 6, Table 3) with comparable yields. Furthermore, Protocol A was applied to the synthesis of bisnaphthofuran 40 (Entry 7, Table 3) in good yield (74\%). The slower rate of reaction and lower yield of the ring-contraction of the $3 H$-naphtho[2,1-b]pyran 29 (Entry 2, Table 3) was possibly due to the increased steric encumberment of the phenyl at C-1. Furthermore, Protocol A was also employed to the ring-contraction of the benzo-1,2-dihydroisoquinoline $\mathbf{4 1}$ which afforded the corresponding benzindole $\mathbf{4 2}$ in $80 \%$ yield (Entry 8, Table 3).

The developed protocols ( $\mathbf{A}$ and $\mathbf{B}$ ) were also applied to the ring-contraction of the isomeric $2 H$-naphtho[1,2-b]pyrans $\mathbf{4 3}$, affording the corresponding naphtho[1,2-b]furans and unsymmetrical naphthodifurans 44 though in diminished yield (19-47\%) (Scheme 13 and Table 4). It is generally established that the $2 H$-naphtho[1,2-b]pyrans are more prone to degradation when compared to the isomeric $3 H$-naphtho[2,1-b]pyrans and this feature might have contributed to the lower yields. ${ }^{33}$ Moreover, protocol B, with the higher reaction temperature, led to more decomposition when compared to protocol $\mathbf{A}$.

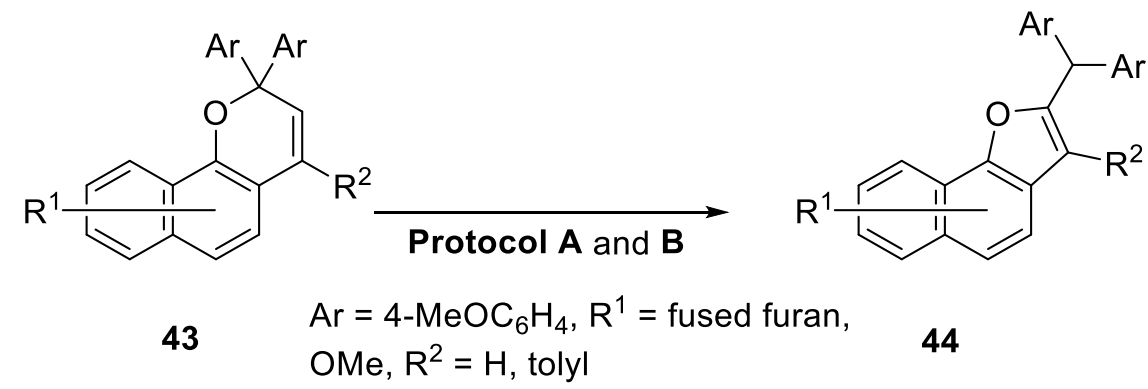

Protocol A: $\mathrm{K}_{2} \mathrm{CO}_{3}$ (1.5 equiv), 18-crown-6 (3.0 equiv), PhMe, reflux, $\mathrm{N}_{2}$; Protocol B: $\mathrm{Pd}(\mathrm{OAc})_{2}(10 \mathrm{~mol} \%), \mathrm{KOAc}$ (2.0 equiv), TBAB (1 equiv), DMAc, $150{ }^{\circ} \mathrm{C}, \mathrm{N}_{2}$

Scheme 13. Reagents and conditions for the optimised protocols for the ringcontraction of substituted $2 H$-naphtho[1,2-b]pyrans 
Table 4. Selected examples of the ring-contraction of substituted $2 H$-naphtho[1,2$b]$ pyrans $\left(\mathrm{Ar}=4-\mathrm{MeOC}_{6} \mathrm{H}_{4}\right)$

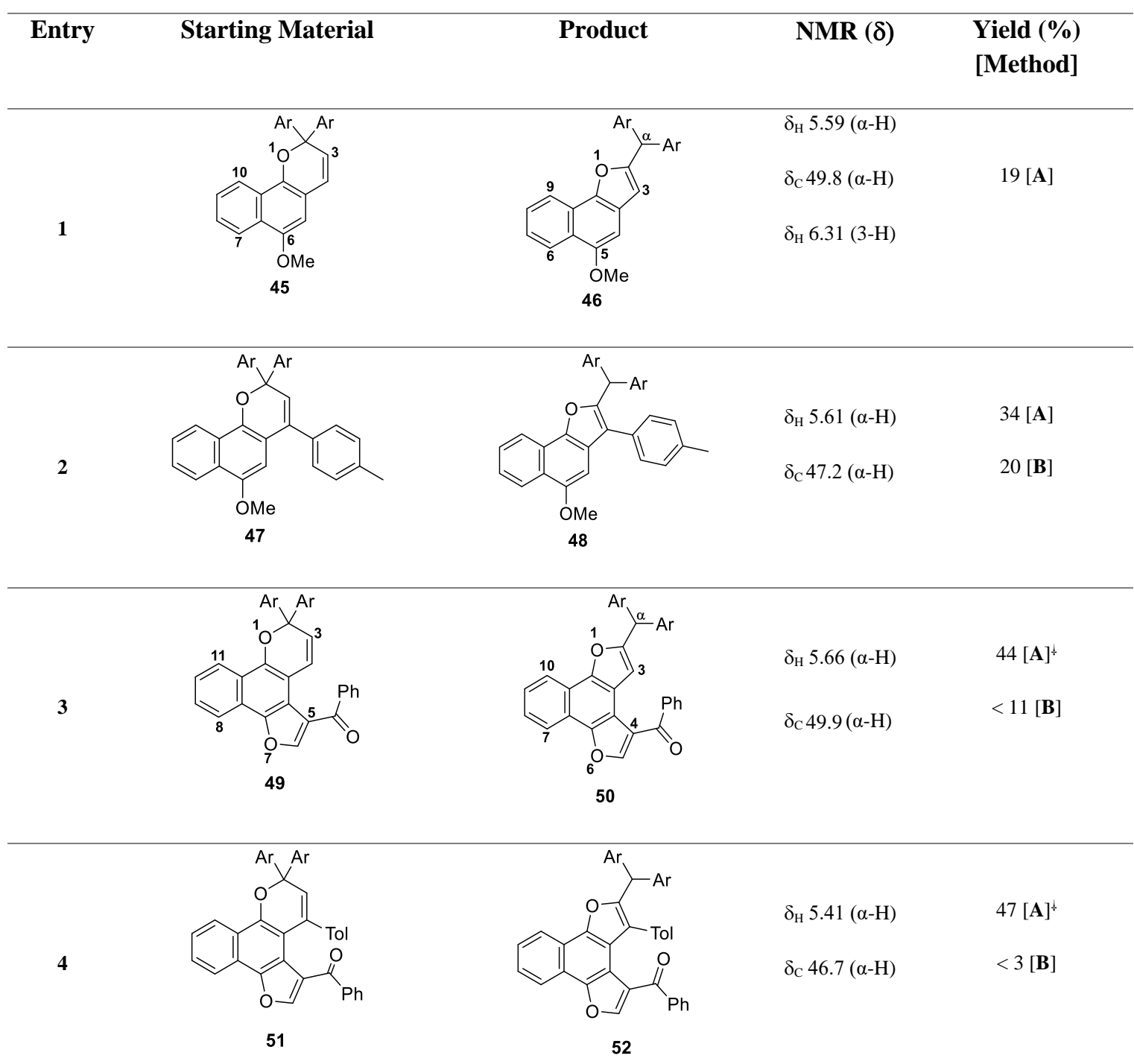

$44 \mathrm{~mol} \%$ of $\mathrm{Pd}(\mathrm{OAc})_{2}$ added.

In summary, Protocols A and $\mathbf{B}$ were similarly effective to perform the ring-contraction of $3 \mathrm{H}$ naphtho[2,1-b]pyrans of different electronic and steric nature, however Protocol A proved to be more suitable for the ring-contraction of the more thermally sensitive $2 H$-naphtho[1,2b]pyrans. Moreover, because the expensive palladium catalyst has a relatively small effect on the rate of ring-contraction of the naphthopyrans, its addition may be avoided. 
Another interesting finding was that, by employing $\mathrm{K}_{2} \mathrm{CO}_{3}$ (1.5 equiv), $\mathrm{Pd}\left(\mathrm{PPh}_{3}\right)_{4}(5 \mathrm{~mol} \%)$ and 18-crown-6 (3.1 equiv) in toluene at reflux for $19 \mathrm{~h}$, the 8-bromo-3H-naphtho[2,1-b]pyran 53 was successfully coupled to 4-pyridineboronic acid pinacol ester 54 affording the 8-(4pyridyl)-3H-naphtho[2,1-b]pyran that ring-contracted in situ to the corresponding naphtho[1,2$b$ ]furan 55. The latter was isolated as the single product of the reaction and was obtained in $47 \%$ yield after flash column chromatography (Scheme 14). The foregoing reaction conditions constitute an effective protocol to selectively prepare, in one step, (hetero)aryl substituted naphthofurans via a Suzuki-coupling - ring-contraction process .<smiles>Brc1ccc2c3c(ccc2c1)OC(Br)(Br)C=C3</smiles>

53

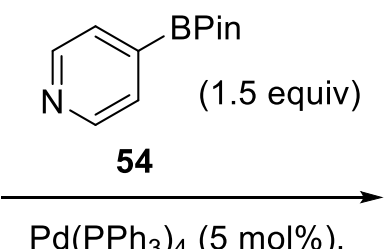

$\mathrm{K}_{2} \mathrm{CO}_{3}(1.5$ equiv) 18-crown-6 (3.1 equiv) PhMe, reflux, $\mathrm{N}_{2}$ $\mathrm{Ar}=4-\mathrm{MeOC}_{6} \mathrm{H}_{4}$ Pin $=$ pinacol<smiles>CC(Br)C(Br)c1cc2c(ccc3cc(-c4ccncc4)c(C(C)(C)C)cc32)o1</smiles>

$\operatorname{Pd}\left(\mathrm{PPh}_{3}\right)_{4}(5 \mathrm{~mol} \%)$,
$\mathrm{KF}(1.5$ or 3.0 equiv),
$\begin{aligned} & \mathrm{PhMe}: \mathrm{EtOH}(1: 1), \\ & \text { reflux, } \mathrm{N}_{2}\end{aligned}$<smiles>BrC1(Br)C=Cc2c(ccc3cc(-c4ccncc4)ccc23)O1</smiles>

56 67\% (KF 1.5 equiv) $59 \%$ (KF 3.0 equiv)

Scheme 14. Reaction conditions illustrating selective Suzuki coupling - ringcontraction and selective Suzuki coupling 
The ring-contraction of naphthopyrans in palladium-catalysed cross-coupling reactions is very often a nuisance. The formation of naphthofurans as by-products constitutes a very significant practical problem, as the purification by flash column chromatography is extremely difficult due to the similar $\mathrm{R}_{\mathrm{f}}$ of the structural isomers in both a variety of mobile and stationary phases. With a view to accomplishing a Suzuki cross-coupling between naphthopyran $\mathbf{5 3}$ and boronic acid ester 54, without the competing ring-contraction, we elected to employ monobasic $\mathrm{KF}$, a weaker base than those employed in the kinetic experiments (Table 1), since KF had found success in Suzuki cross-coupling reactions. ${ }^{34}$

Thus, when using KF (1.5 equiv) and $\mathrm{Pd}\left(\mathrm{PPh}_{3}\right)_{4}(5 \mathrm{~mol} \%)$ in $\mathrm{PhMe}: \mathrm{EtOH}(1: 1)$ at reflux, 8 bromo-3H-naphtho[2,1-b]pyran $\mathbf{5 3}$ was successfully coupled to 4-pyridineboronic acid pinacol ester 54 affording the 8-(4-pyridyl)-3H-naphtho[2,1-b]pyran 56 in $67 \%$ yield, without the formation of the corresponding naphtho[2,1-b]furan $\mathbf{5 5}$ as a by-product (Scheme 14).

One implication of the Suzuki cross-coupling mechanism is that the base is effectively consumed during the catalytic cycle. Since the rate of the Suzuki cross-coupling reaction is generally faster than the rate of the ring-contraction, it was rationalized that employing only 1.5 equiv of KF, no base would be left available to promote the ring-contraction, as it had been consumed during the Suzuki cross-coupling process. However, it was deemed important to explore the likelihood of ring-contraction where excess KF was present. Thus, the use of excess $\mathrm{KF}$ (3.0 equiv) with the foregoing cross-coupling conditions again effected smooth conversion to $56(59 \%)$ without any ring-contraction. This developed protocol (unoptimised) allows Suzuki cross-coupling reactions to be performed with naphthopyrans without the ringcontraction side reaction and strongly suggests that the ring-contraction is dependent upon the basicity of the base; thus for selective Suzuki coupling the use of KF is recommended. 


\section{Conclusions}

The ring-contraction of the model 3,3-bis(4-methoxyphenyl) substituted 3H-naphtho[2,1b]pyran 21 has been investigated and found to operate by two independent processes: one involving Pd-catalysis and the other mediated only by the carbonate base. Optimisation of these processes has enabled a series of novel diarylmethyl substituted naphthofurans and a series of symmetrical and unsymmetrical naphthodifurans to be efficiently isolated in good yield. The methodology has been further extended to provide the first example of a ringcontraction of a 3,4-dihydrobenzoquinoline ring to a benzoindole.

By judicious choice of the optimised reaction conditions either a Pd-mediated Suzuki crosscoupling - ring-contraction of a bromonaphthopyran to afford an (hetero)aryl substituted naphthofuran or a selective Pd-mediated Suzuki cross-coupling reaction to afford a (hetero)aryl substituted naphthopyran can be accomplished. Given the wide interest in synthesising complex photochromic naphthopyran containing materials ${ }^{35}$ which rely upon Pd-mediated methodologies we believe that the latter optimised, selective protocol will be useful to materials scientists.

\section{Experimental Section}

Unless otherwise stated, reagents and solvents were purchased from major chemical catalogue companies and were used as supplied. For reactions requiring heating, DrySyn ${ }^{\circledR}$ aluminium heating blocks in conjunction with electrical stirrer hotplates were used as the heat source. Substrates for ring-contraction were to hand within the department. ${ }^{1} \mathrm{H}$ NMR (400 MHz) and ${ }^{13} \mathrm{C}\left\{{ }^{1} \mathrm{H}\right\}$ NMR $(100 \mathrm{MHz})$ spectra were recorded on a Bruker Avance DPX400 in either $\mathrm{CDCl}_{3}$ or d6-DMSO unless stated otherwise. Chemical shifts are provided in parts per million (ppm) using either the residual solvent peak or TMS as the internal reference. 2D NMR experiments (COSY, HSQC and HMBC) were performed on specific examples to unequivocally sign the 
protons of the molecules. Coupling constants $(J)$ are provided in Hz. FT-IR spectra were recorded on a Nicolet 380 FTIR spectrophotometer equipped with a diamond ATR attachment (neat sample). Flash column chromatography was performed on chromatography silica gel (either Sigma-Aldrich, 40-63 micron particle size distribution or Fluorochem Silica gel 40-63 micron particle size distribution). All final compounds were homogeneous by TLC using a range of eluent systems of differing polarity (either Merck TLC aluminium sheets silica gel 60 F254 (cat. No 105554) or Fluorochem cat. No. LC0927). Melting points were determined in capillary tubes, using a Stuart SMP10 melting point apparatus, and are uncorrected. Accurate mass measurements were obtained from the Innovative Physical Organic Solutions (IPOS) centre at the University of Huddersfield.

The following benzochromene (naphthopyran) substrates used in this study were prepared according to literature procedures and possessed physical and spectroscopic properties that were in excellent agreement with those previously reported in the literature for their preparation: $\quad$ 3,3-bis(4-methoxyphenyl)-3H-benzo[f]chromene $\quad \mathbf{2 1} ;^{36} \quad$ 4-(3,3-bis(4methoxyphenyl)-3H-benzo[f]chromen-6-yl)morpholine $\quad 31 ;^{37} \quad 3$-(4-methoxyphenyl)-3(thiophen-2-yl)-3H-benzo[f]chromene $\quad \mathbf{3 3} ;^{38} \quad$ 2,2,11,11-tetrakis(4-methoxyphenyl)-2,11dihydrobenzo[f]pyrano[3,2- $h]$ chromene $\quad 37, ;^{39} \quad$ 2,2,8,8-tetrakis(4-methoxyphenyl)-2,8dihydrochromeno[6,5-f]chromene $\quad 39 ;{ }^{40} \quad$ 6-methoxy-2,2-bis(4-methoxyphenyl)-2Hbenzo $[h]$ chromene $\quad \mathbf{4 5} ;^{41} \quad$ 6-methoxy-2,2-bis(4-methoxyphenyl)-4-(p-tolyl)-2Hbenzo $[h]$ chromene $\quad 47{ }^{41} \quad$ (6,6-bis(4-methoxyphenyl)-6H-benzo[ $\left.h\right]$ furo[3,2-f]chromen-3yl)(phenyl)methanone $\quad \mathbf{4 9} ;{ }^{42} \quad$ (6,6-bis(4-methoxyphenyl)-4-( $p$-tolyl)-6H-benzo[ $\left.h\right]$ furo[3,2f]chromen-3-yl)(phenyl)methanone $\quad \mathbf{5 1}^{42}$ and 8-bromo-3,3-bis(4-methoxyphenyl)-3Hbenzo[f]chromene $\mathbf{5 3}{ }^{40}$ 


\section{Preparation of Novel Substrates}

Synthesis of 3,3-Bis(4-methoxyphenyl)-1-(p-tolyl)-3H-benzo[f]chromene 29: a solution of 2-naphthol (1.01 g, 6.94 mmol), 1,1-bis(4-methoxyphenyl)-3-(p-tolyl)prop-2-yn-1-ol (2.55 g, $7.11 \mathrm{mmol})$, pyridinium $p$-toluenesulfonate (PPTS) (0.18 g, $0.69 \mathrm{mmol})$ and trimethyl orthoformate $(1.52 \mathrm{~mL}, 13.9 \mathrm{mmol})$ in 1,2-dichloroethane $(75 \mathrm{~mL})$ was heated under reflux $\left(250 \mathrm{~mL}, 2\right.$-neck RBF, $\left.100{ }^{\circ} \mathrm{C}\right)$ until no propynol remained as indicated by TLC (30\% EtOAc / hexane, $3 \mathrm{~h}$ ). The solvent was removed from the cooled reaction mixture and the resulting solid triturated with hexane/EtOAc. The resulting pale solid was collected by vacuum filtration, rinsed with hexane and allowed to dry, giving a pale yellow solid. Purified via recrystallization from EtOAc/hexane to afford 3,3-bis(4-methoxyphenyl)-1-(p-tolyl)-3H-benzo[f]chromene $(1.77$ g, Yield $=53 \%)$. m.p. $=117-119{ }^{\circ} \mathrm{C} ; v_{\max }$ (neat) $2961,2834,1738,1607,1507 \mathrm{~cm}^{-1} ;{ }^{1} \mathrm{H}$ NMR (400 MHz, CDCl 3$) \delta_{\mathrm{H}} 2.41(3 \mathrm{H}, \mathrm{s}$, Tol-H), $3.75(6 \mathrm{H}, \mathrm{s}, \mathrm{An}-\mathrm{H}), 6.14(1 \mathrm{H}, \mathrm{s}, 2-\mathrm{H}), 6.81$ (4H, app. d, $\left.J=8.8 \mathrm{~Hz}, 3^{\prime}, 3^{\prime \prime}, 5^{\prime}, 5^{\prime \prime}-\mathrm{H}\right), 7.04(1 \mathrm{H}$, app. t, $J=8.2 \mathrm{~Hz}, \mathrm{Ar}-\mathrm{H}), 7.16-7.26(6 \mathrm{H}$, m, Ar-H), $7.31(1 \mathrm{H}, \mathrm{d}, J=8.8 \mathrm{~Hz}, \mathrm{Ar}-\mathrm{H}), 7.44\left(4 \mathrm{H}\right.$, app. d, $\left.J=8.8 \mathrm{~Hz}, 2^{\prime}, 2^{\prime \prime}, 6^{\prime}, 6^{\prime \prime}-\mathrm{H}\right), 7.67-$ $7.71(2 \mathrm{H}, \mathrm{m}, \mathrm{Ar}-\mathrm{H}) ;{ }^{13} \mathrm{C}\left\{{ }^{1} \mathrm{H}\right\} \mathrm{NMR}\left(400 \mathrm{MHz}, \mathrm{CDCl}_{3}\right) \delta_{\mathrm{C}} 21.3 ; 55.2,81.9,113.3,116.7,118.8$, $123.1,124.9,126.6,127.9,128.3,128.5,129.1,129.4,129.9,130.2,130.7,136.7,136.8,137.3$, 138.4, 152.6, 158.8; HRMS (ESI) m/z: $[\mathrm{M}+\mathrm{H}]^{+}$Calcd for $\mathrm{C}_{34} \mathrm{H}_{29} \mathrm{O}_{3}{ }^{+}$485.2106; Found 485.2111.

\section{Synthesis of 3,3,10,10-Tetrakis(4-methoxyphenyl)-3H,10H-chromeno[5,6-f]chromene 35:}

a solution of 2,7-dihydroxynaphthalene (1 mmol), 1,1-bis(4-methoxyphenyl)prop-2-yn-1-ol (2.1 mmol), pyridinium $p$-toluenesulfonate (PPTS) $(10 \mathrm{~mol} \%)$ and trimethyl orthoformate (4 $\mathrm{mmol})$ in 1,2-dichloroethane $(6 \mathrm{~mL})$ was heated under reflux until no propynol remained as indicated by TLC (30\% EtOAc / hexane) examination of the reaction mixture (ca. $2.5 \mathrm{~h})$. The solvent was removed from the reaction mixture and the resulting solid triturated with 
hexane/EtOAc. The resulting pale solid was collected by vacuum filtration, rinsed with hexane and allowed to dry, giving a pale yellow solid. Washings with hot EtOH and EtOAc afforded the desired product as an off-white powder $(3.37 \mathrm{~g}$, Yield $=82 \%)$; m.p. $=220-223{ }^{\circ} \mathrm{C}$; $v_{\max }$ (neat) $1608,1509,1298,1251,1172,1034,985,954,836,729,580 \mathrm{~cm}^{-1}$; Photomerocyanine $\lambda_{\max }=448 \mathrm{~nm}(\mathrm{PhMe}) ;{ }^{1} \mathrm{H} \mathrm{NMR}\left(400 \mathrm{MHz}, \mathrm{CDCl}_{3}\right) \delta_{\mathrm{H}} 3.77(\mathrm{~s}, 12 \mathrm{H}, \mathrm{OMe}), 6.00(\mathrm{~d}, 2 \mathrm{H}, J=$ $9.6 \mathrm{~Hz}, 2,11-\mathrm{H}), 6.83$ (app. d, 8H, $\left.J=8.9 \mathrm{~Hz}, 3^{\prime}, 5^{\prime}, 3^{\prime \prime}, 5^{\prime \prime}, 3^{\prime \prime \prime}, 5^{\prime \prime \prime}, 3^{\prime \prime \prime \prime}, 5^{\prime \prime \prime \prime \prime}-\mathrm{H}\right), 7.00$ (d, 2H, $J=8.7 \mathrm{~Hz}, 5,8-\mathrm{H}), 7.11(\mathrm{~d}, 2 \mathrm{H}, J=9.6 \mathrm{~Hz}, 1,12-\mathrm{H}), 7.40$ (app. d, 8H, $J=8.8 \mathrm{~Hz}, 2^{\prime}, 6^{\prime}, 2^{\prime \prime}$, $\left.6^{\prime \prime}, 2^{\prime \prime \prime}, 6^{\prime \prime \prime}, 2^{\prime \prime \prime \prime}, 66^{\prime \prime \prime \prime \prime}-\mathrm{H}\right), 7.49(\mathrm{~d}, 2 \mathrm{H}, J=8.7 \mathrm{~Hz}, 6,7-\mathrm{H}) \mathrm{ppm} ;{ }^{13} \mathrm{C}\left\{{ }^{1} \mathrm{H}\right\}$ NMR $(100 \mathrm{MHz}$, $\left.\mathrm{CDCl}_{3}\right) \delta_{\mathrm{C}} 55.2,81.8,113.3,114.7,115.8,124.4,124.7,125.6,128.5,128.5,130.9,137.0$, 152.8, 158.9 ppm; HRMS (ESI) m/z: [M+H] ${ }^{+}$Calcd for $\mathrm{C}_{44} \mathrm{H}_{37} \mathrm{O}_{6}{ }^{+}$661.2585; Found 661.2585.

\section{Synthesis of 4-(3,3,4-Tris(4-methoxyphenyl)-3,4-dihydrobenzo[f]quinolin-6-}

yl)morpholine 41: acidic alumina (3.0 g) was added in a single portion to a stirred warmed (ca. $\left.40^{\circ} \mathrm{C}\right)$ solution of 1,1-bis(4-methoxyphenyl)prop-2-yn-1-ol $(0.81 \mathrm{~g}, 3.0 \mathrm{mmol})$ and $N$-(4methoxyphenyl)-4-morpholinonaphthalen-2-amine $(1.0 \mathrm{~g}, 3.0 \mathrm{mmol})$ in toluene $(50 \mathrm{~mL})$. The solution was heated to reflux for $3 \mathrm{~h}$ and then cooled to $c a .60^{\circ} \mathrm{C}$ whereupon the mixture was filtered to remove the $\mathrm{Al}_{2} \mathrm{O}_{3}$ catalyst. The catalyst was washed with EtOAc $(2 \times 30 \mathrm{~mL})$ and the combined filtrates evaporated to afford a brown gum which was subjected to flash column chromatography [Aldrich silica gel (60 ̊, 230-400 mesh, 40-63 $\mu \mathrm{m})$, eluent: EtOAc $(20 \%)$ in hexanes, fraction 2] followed by crystallization from a mixture of DCM/hexane, providing the title product as a pale pink crystalline solid $(0.77 \mathrm{~g}, 1.3 \mathrm{mmol}, 44 \%) ; \mathrm{m} . \mathrm{p} .=211-212{ }^{\circ} \mathrm{C} ; v_{\max }$ (neat) $2947,2839,1607,1583,1505,1441,1246,1173,1116,1027,836,737,538 \mathrm{~cm}^{-1} ;{ }^{1} \mathrm{H}$ NMR (400 MHz, $\left.\mathrm{CDCl}_{3}\right) \delta_{\mathrm{H}} 2.87\left(4 \mathrm{H}, \mathrm{bs}, \mathrm{N}\left(\mathrm{CH}_{2}\right)_{2}\right), 3.71$ (3H, s, OMe), $3.74(6 \mathrm{H}, \mathrm{s}, \mathrm{OMe})$, $3.87\left(4 \mathrm{H}, \mathrm{t}, J=4.4 \mathrm{~Hz}, \mathrm{O}\left(\mathrm{CH}_{2}\right)_{2}\right), 5.98(1 \mathrm{H}, \mathrm{d}, J=9.7 \mathrm{~Hz}, 2-\mathrm{H}), 6.32(1 \mathrm{H}, \mathrm{s}, 5-\mathrm{H}), 6.57(2 \mathrm{H}$, app. d, $J=8.8 \mathrm{~Hz}, \operatorname{Ar}-\mathrm{H}), 6.72(4 \mathrm{H}$, app. d, $J=8.7 \mathrm{~Hz}, \operatorname{Ar}-\mathrm{H}), 6.83(2 \mathrm{H}$, app. d, $J=8.8 \mathrm{~Hz}$, 
Ar-H), 7.15-7.22 (2H, m, Ar-H), 7.26-7.29 (5H, m, Ar-H), 7.37 (1H, t, J = 7.6 Hz, 9-H), 7.89

$(1 \mathrm{H}, \mathrm{d}, J=8.5 \mathrm{~Hz}, 10-\mathrm{H}), 8.01(1 \mathrm{H}, \mathrm{d}, J=8.4 \mathrm{~Hz}, 7-\mathrm{H}) \mathrm{ppm} ;{ }^{13} \mathrm{C}\left\{{ }^{1} \mathrm{H}\right\} \mathrm{NMR}\left(100 \mathrm{MHz}, \mathrm{CDCl}_{3}\right)$ $\delta_{\mathrm{C}} 53.2,55.19,55.24,67.4,70.3,107.8,109.3,112.8,113.8,117.6,121.6,121.7,122.6,123.7$, 126.6, 128.0, 130.0, 131.6, 131.7, 137.7, 138.0, 142.3, 149.8, 157.0, 158.2 ppm; HRMS (ESI) m/z: $[\mathrm{M}+\mathrm{H}]^{+}$Calcd for $\mathrm{C}_{38} \mathrm{H}_{37} \mathrm{~N}_{2} \mathrm{O}_{4}{ }^{+}$585.2748; Found 585.2746.

\section{Ring-Contraction Experiments}

1. Kinetic Study of the Ring-Contraction of 3,3-Bis(4-methoxyphenyl)-3H-naphtho[2,1b]pyran 21

Entry 1, Table 1. 3,3-Bis(4-methoxyphenyl)-3H-naphtho[2,1-b]pyran 21 (0.01 g, 0.03 mmol) was dissolved in DCM and stirred in a sealed flask at room temperature. After $18 \mathrm{~h},{ }^{1} \mathrm{H}$ NMR analysis had shown no change in the reaction mixture.

Entry 2, Table 1. 3,3-Bis(4-methoxyphenyl)-3H-naphtho[2,1-b]pyran 21 (0.01 g, 0.03 mmol) was dissolved in PhMe and stirred in a sealed flask at room temperature. After $17 \mathrm{~h},{ }^{1} \mathrm{H}$ NMR analysis had shown no change in the reaction mixture.

Entry 3, Table 1. 3,3-Bis(4-methoxyphenyl)-3H-naphtho[2,1-b]pyran 21 (0.01 g, 0.03 mmol) was mixed in $\mathrm{EtOH}$ and stirred in a sealed flask at room temperature. After $28 \mathrm{~h},{ }^{1} \mathrm{H}$ NMR analysis had shown no change in the reaction mixture.

Entry 4, Table 1. 3,3-Bis(4-methoxyphenyl)-3H-naphtho[2,1-b]pyran 21 (0.01 g, 0.03 mmol) was dissolved in PhMe:EtOH (1:1) and stirred in a sealed flask at room temperature. After 15 h, ${ }^{1} \mathrm{H}$ NMR analysis had shown no change in the reaction mixture. 3,3-Bis(4-methoxyphenyl)3H-naphtho[2,1-b]pyran 21 (0.01 g, $0.03 \mathrm{mmol})$ was dissolved in PhMe:EtOH (1:1) and stirred in a reaction vessel at reflux. After $14 \mathrm{~h},{ }^{1} \mathrm{H}$ NMR analysis had shown no change in the reaction mixture. 
Entry 5, Table 1. 3,3-Bis(4-methoxyphenyl)-3H-naphtho[2,1-b]pyran 21 (0.01 g, 0.03 mmol) was dissolved in DMAc and stirred in a sealed flask at room temperature. After $28 \mathrm{~h},{ }^{1} \mathrm{H}$ NMR analysis had shown no change in the reaction mixture. 3,3-Bis(4-methoxyphenyl)-3Hnaphtho[2,1-b]pyran 21 (0.01 g, $0.03 \mathrm{mmol})$ was dissolved in DMAc and stirred in a reaction vessel at $150{ }^{\circ} \mathrm{C}$. After $14 \mathrm{~h},{ }^{1} \mathrm{H}$ NMR analysis had shown no change in the reaction mixture.

Entry 6, Table 1. 3,3-Bis(4-methoxyphenyl)-3H-naphtho[2,1-b]pyran 21 (0.01 g, 0.03 mmol) was dissolved in DCM and a catalytic amount of $\mathrm{Pd}\left(\mathrm{PPh}_{3}\right)_{4}$ was added, and stirred in a sealed flask at room temperature. After $23 \mathrm{~h},{ }^{1} \mathrm{H}$ NMR analysis had shown no change in the reaction mixture

Entry 7, Table 1. 3,3-Bis(4-methoxyphenyl)-3H-naphtho[2,1-b]pyran 21 (250.2 mg, 0.6343 $\mathrm{mmol}), \mathrm{K}_{2} \mathrm{CO}_{3}(126.2 \mathrm{mg}, 0.9131 \mathrm{mmol})$ and $\mathrm{Pd}\left(\mathrm{PPh}_{3}\right)_{4}(35.2 \mathrm{mg}, 0.0305 \mathrm{mmol})$ were dissolved in PhMe (6 mL) and EtOH (6 mL), and refluxed under $\mathrm{N}_{2}$ for $48 \mathrm{~h} .{ }^{1} \mathrm{H}$ NMR analysis showed a 1.0:3.5 (21:22) mixture.

Entry 8, Table 1. 3,3-Bis(4-methoxyphenyl)-3H-naphtho[2,1-b]pyran 21 (0.51 g, 1.3 mmol) and KOAc (0.25 g, $2.5 \mathrm{mmol})$ were dissolved in DMAc $(20 \mathrm{~mL})$ and degassed with $\mathrm{N}_{2}$ for 15 minutes at room temperature. Then $\mathrm{Pd}(\mathrm{OAc})_{2}(0.0287 \mathrm{~g}, 0.127 \mathrm{mmol})$ was added and the mixture heated to $150{ }^{\circ} \mathrm{C}$, and the reaction followed by TLC (25\% EtOAc in hexanes). After 5 $\mathrm{h}$, the reaction mixture was added to water $(100 \mathrm{~mL})$ and extracted with DCM $(3 \times 50 \mathrm{~mL})$. The combined organic layers were washed with water $(3 \times 50 \mathrm{~mL})$, the organic layer reduced, re-dissolved in EtOAc $(50 \mathrm{~mL})$ and filtered. The filtrate was washed with brine $(8 \times 50 \mathrm{~mL})$ and the organic layer reduced to afford the crude product $(0.35 \mathrm{~g}) .{ }^{1} \mathrm{H}$ NMR analysis showed a 1.0:1.1 (21:22) mixture. 
Entry 9, Table 1. 3,3-Bis(4-methoxyphenyl)-3H-naphtho[2,1-b]pyran 21 (250.9 mg, 0.6360 mmol) and $\mathrm{K}_{2} \mathrm{CO}_{3}(125.7 \mathrm{mg}, 0.9095 \mathrm{mmol})$ were dissolved in $\mathrm{PhMe}(6 \mathrm{~mL})$ and $\mathrm{EtOH}(6$ $\mathrm{mL}$ ), and refluxed under $\mathrm{N}_{2} .{ }^{1} \mathrm{H}$ NMR analysis showed a 1.0:2.0 (21:22) mixture after $80 \mathrm{~h}$.

Entry 10, Table 1. 3,3-Bis(4-methoxyphenyl)-3H-naphtho[2,1-b]pyran (100.0 mg, 0.2535 $\mathrm{mmol}), \mathrm{K}_{2} \mathrm{CO}_{3}(105.1 \mathrm{mg}, 0.7605 \mathrm{mmol})$ in $\mathrm{PhMe}(3 \mathrm{~mL})$ and ethanol $(3 \mathrm{~mL})$ was heated at reflux under $\mathrm{N}_{2}{ }^{1} \mathrm{H}$ NMR analysis showed full conversion to 22 after $74 \mathrm{~h}$.

Entry 11, Table 1. 3,3-Bis(4-methoxyphenyl)-3H-naphtho[2,1- $b$ ]pyran 21 (250.2 mg, 0.6343 $\mathrm{mmol})$ and $\mathrm{Pd}\left(\mathrm{PPh}_{3}\right)_{4}(35.3 \mathrm{mg}, 0.0305 \mathrm{mmol})$ were dissolved in $\mathrm{PhMe}(6 \mathrm{~mL})$ and $\mathrm{EtOH}(6$ $\mathrm{mL}$ ), and refluxed under $\mathrm{N}_{2}$ for $48 \mathrm{~h} .{ }^{1} \mathrm{H}$ NMR analysis had shown no change in the reaction mixture.

Entry 12, Table 1. 3,3-Bis(4-methoxyphenyl)-3H-naphtho[2,1-b]pyran (200.9 mg, 0.5093 mmol), $\mathrm{Cs}_{2} \mathrm{CO}_{3}(248.3 \mathrm{mg}, 0.7621 \mathrm{mmol})$ were dissolved in $\mathrm{PhMe}(5 \mathrm{~mL})$ and $\mathrm{EtOH}(5 \mathrm{~mL})$, and refluxed under $\mathrm{N}_{2} .{ }^{1} \mathrm{H}$ NMR analysis showed a 1.0:2.0 (21:22) mixture after $80 \mathrm{~h}$.

Entry 13, Table 1. 3,3-Bis(4-methoxyphenyl)-3H-naphtho[2,1-b]pyran (200.9 mg, 0.5093 mmol), $\mathrm{Li}_{2} \mathrm{CO}_{3}(56.7 \mathrm{mg}, 0.767 \mathrm{mmol})$ were dissolved in $\mathrm{PhMe}(5 \mathrm{~mL})$ and $\mathrm{EtOH}(5 \mathrm{~mL})$, and refluxed under $\mathrm{N}_{2} .{ }^{1} \mathrm{H}$ NMR analysis showed a 1.8:1.0 (21:22) mixture after $80 \mathrm{~h}$.

Entry 14, Table 1. 3,3-Bis(4-methoxyphenyl)-3H-naphtho[2,1-b]pyran (200.6 mg, 0.5085 mmol), $\mathrm{Na}_{2} \mathrm{CO}_{3}(80.7 \mathrm{mg}, 0.761 \mathrm{mmol})$ were dissolved in $\mathrm{PhMe}(5 \mathrm{~mL})$ and $\mathrm{EtOH}(5 \mathrm{~mL})$, and refluxed under $\mathrm{N}_{2} .{ }^{1} \mathrm{H}$ NMR analysis showed a 1.1:1.0 (21:22) mixture after $80 \mathrm{~h}$.

Entry 15, Table 1. 3,3-Bis(4-methoxyphenyl)-3H-naphtho[2,1- $b]$ pyran (199.8 mg, 0.5065 mmol), $\mathrm{K}_{3} \mathrm{PO}_{4}(161.4 \mathrm{mg}, 0.7604 \mathrm{mmol})$ were dissolved in PhMe (5 mL) and EtOH (5 mL), and refluxed under $\mathrm{N}_{2} .{ }^{1} \mathrm{H}$ NMR analysis showed a 1.7:1.0 (21:22) mixture after $14 \mathrm{~h}$. 
Entry 1, Table 2. 3,3-Bis(4-methoxyphenyl)-3H-naphtho[2,1-b]pyran 21 (250.9 mg, 0.6360 mmol) and $\mathrm{K}_{2} \mathrm{CO}_{3}(125.7 \mathrm{mg}, 0.9095 \mathrm{mmol})$ were dissolved in $\mathrm{PhMe}(6 \mathrm{~mL})$ and $\mathrm{EtOH}(6$ $\mathrm{mL}$ ), and refluxed under $\mathrm{N}_{2}$. Several samples were obtained over time and subjected to ${ }^{1} \mathrm{H}$ NMR analysis.

Entry 2, Table 2. 3,3-Bis(4-methoxyphenyl)-3H-naphtho[2,1-b]pyran 21 (199.9 mg, 0.5068 $\mathrm{mmol}), \mathrm{K}_{2} \mathrm{CO}_{3}(105.0 \mathrm{mg}, 0.7597 \mathrm{mmol})$ and 18 -crown-6 (415.3 mg, $\left.1.571 \mathrm{mmol}\right)$ were dissolved in $\mathrm{PhMe}(10 \mathrm{~mL})$, and refluxed under $\mathrm{N}_{2}$. Several samples were obtained over time and subjected to ${ }^{1} \mathrm{H}$ NMR analysis.

Entry 3, Table 2. 3,3-Bis(4-methoxyphenyl)-3H-naphtho[2,1-b]pyran 21 (152.8 mg, 0.3874 mmol) and 18-crown-6 (387.4 mg, $1.221 \mathrm{mmol})$ were dissolved in PhMe (7.4 mL), and refluxed under $\mathrm{N}_{2} .{ }^{1} \mathrm{H}$ NMR analysis had shown no change in the reaction mixture.

Entry 4, Table 2. 3,3-Bis(4-methoxyphenyl)-3H-naphtho[2,1-b]pyran (427.7 mg, 1.084 mmol), $\mathrm{K}_{2} \mathrm{CO}_{3}(14.9 \mathrm{mg}, 0.108 \mathrm{mmol})$ and 18-crown-6 (57.0 mg, $\left.0.216 \mathrm{mmol}\right)$ were dissolved in $\mathrm{PhMe}(28 \mathrm{~mL})$, and refluxed under $\mathrm{N}_{2}$. Several samples were obtained over time and subjected to ${ }^{1} \mathrm{H}$ NMR analysis.

Entry 5, Table 2. 3,3-Bis(4-methoxyphenyl)-3H-naphtho[2,1-b]pyran (120.5 mg, 0.3055 $\mathrm{mmol}), \mathrm{K}_{2} \mathrm{CO}_{3}(62.7 \mathrm{mg}, 0.454 \mathrm{mmol}), 18$-crown-6 (243.6 mg, $\left.0.9216 \mathrm{mmol}\right)$ and $\mathrm{Pd}(\mathrm{OAc})_{2}$ (2.6 mg, $0.012 \mathrm{mmol})$ were dissolved in PhMe $(6.0 \mathrm{~mL})$, and refluxed under $\mathrm{N}_{2}$. Several samples were obtained over time and subjected to ${ }^{1} \mathrm{H}$ NMR analysis.

\section{General Experimental Procedure for the Pyran (Dihydroquinoline) Ring-Contraction}

Protocol A: a mixture of naphthopyran (1.3 mmol), 18-crown-6 (3.93 mmol), $\mathrm{K}_{2} \mathrm{CO}_{3}(1.9$ $\mathrm{mmol})$ in $\mathrm{PhMe}(25.0 \mathrm{~mL})$ was heated at reflux under $\mathrm{N}_{2}$. After the completion of the reaction, the crude was evaporated to dryness. The residue was dissolved in DCM (150 mL), washed 
with water $(3 \times 150 \mathrm{~mL})$, the organic layer dried with anhydrous sodium sulfate and the solvent removed under reduced pressure, giving the corresponding product after purification if needed.

Note: $\mathrm{Pd}(\mathrm{OAc})_{2}(4 \mathrm{~mol} \%)$ was added to the reaction mixture when noted.

Protocol B: a mixture of naphthopyran $(1.27 \mathrm{mmol})$, KOAc $(2.54 \mathrm{mmol})$ and TBAB (1.27 mmol) in anhydrous $N, N$-dimethylacetamide $(20 \mathrm{~mL})$ was deaerated with $\mathrm{N}_{2}$ for 20 min. Hence, $\mathrm{Pd}(\mathrm{OAc})_{2}(10 \mathrm{~mol} \%)$ was added and the mixture heated at $150{ }^{\circ} \mathrm{C}$ until TLC examination of the reaction mixture indicated that no naphthopyran remained. When the reaction was judged to be complete ( $4-8 \mathrm{~h}$ typical reaction time), the crude was cooled, diluted with EtOAc $(150 \mathrm{~mL})$ and filtered. The solution was washed with brine $(6 \times 50 \mathrm{~mL})$ and water $(2 \times 50 \mathrm{~mL})$, before drying with anhydrous sodium sulfate and removal of the solvent. The residue was subjected to flash column chromatography to afford the title compound.

\section{Entry 1, Table 3. 2-(Bis(4-methoxyphenyl)methyl)naphtho[2,1-b]furan 22. Protocol A:} from 3,3-bis(4-methoxyphenyl)-3H-naphtho[2,1-b]pyran $21(0.50 \mathrm{~g}, 1.3 \mathrm{mmol})$ after $9 \mathrm{~h}$ of reaction; crystallization from a mixture of DCM/hexane gave the corresponding product as a yellow crystalline solid $(0.40 \mathrm{~g}, 80 \%)$. Protocol B: from 3,3-bis(4-methoxyphenyl)-3Hnaphtho[2,1-b]pyran 21 (0.50 g, $1.3 \mathrm{mmol})$ after elution from silica gel with EtOAc $(25 \%)$ in hexanes as off-white microcrystals $(0.39 \mathrm{~g}, 78 \%) . \mathrm{m} . \mathrm{p} .=172-173{ }^{\circ} \mathrm{C} ; v_{\max }$ (neat) 1607,1581 , $1505,1440,1243,1176,1027,807,746,584 \mathrm{~cm}^{-1}$; NMR (400 MHz, $\left.\mathrm{CDCl}_{3}\right) \delta_{\mathrm{H}} 3.81(6 \mathrm{H}, \mathrm{s}$, OMe), $5.59(1 \mathrm{H}, \mathrm{s}, \alpha-\mathrm{H}), 6.73(1 \mathrm{H}, \mathrm{s}, 1-\mathrm{H}), 6.88\left(4 \mathrm{H}\right.$, app. d, $\left.J=8.6 \mathrm{~Hz}, 3^{\prime}, 5^{\prime}, 3^{\prime \prime}, 5^{\prime \prime}-\mathrm{H}\right), 7.17$ (4H, app. d, $\left.J=8.6 \mathrm{~Hz}, 2^{\prime}, 6^{\prime}, 2^{\prime \prime}, 6^{\prime \prime}-\mathrm{H}\right), 7.44(1 \mathrm{H}$, app. t, $J=7.5 \mathrm{~Hz}, 8-\mathrm{H}), 7.52(1 \mathrm{H}$, app. t, $J$ $=7.5 \mathrm{~Hz}, 7-\mathrm{H}), 7.58(1 \mathrm{H}, \mathrm{d}, J=9.0 \mathrm{~Hz}, 5-\mathrm{H}), 7.66(1 \mathrm{H}, \mathrm{d}, J=9.0 \mathrm{~Hz}, 4-\mathrm{H}), 7.91(1 \mathrm{H}, \mathrm{d}, J=$ $8.1 \mathrm{~Hz}, 9-\mathrm{H}), 8.01(1 \mathrm{H}, \mathrm{d}, J=8.2 \mathrm{~Hz}, 6-\mathrm{H}) \mathrm{ppm} ;{ }^{13} \mathrm{C}\left\{{ }^{1} \mathrm{H}\right\} \mathrm{NMR}\left(100 \mathrm{MHz}, \mathrm{CDCl}_{3}\right) \delta_{\mathrm{C}} 49.8$, $55.3,104.4,112.4,114.0,123.4,123.6,124.3,124.5,126.1,127.5,128.7,129.8,130.2,133.7$, 
152.4, 158.5, 160.0 ppm; HRMS (ESI) m/z: $[\mathrm{M}+\mathrm{H}]^{+}$Calcd for $\mathrm{C}_{27} \mathrm{H}_{23} \mathrm{O}_{3}{ }^{+}$395.1642; Found 395.1634.

Entry 2, Table 3. 2-(Bis(4-methoxyphenyl)methyl)-1-(p-tolyl)naphtho[2,1-b]furan 30. Protocol A: from 3,3-bis(4-methoxyphenyl)-1-(p-tolyl)-3H-naphtho[2,1-b]pyran 29 (75.6 mg, $0.156 \mathrm{mmol}$ ) after $64 \mathrm{~h}$ of reaction; Purification by preparative TLC [Merck Silica gel $60 \mathrm{~F}_{254}$, EtOAc (10\%) in hexanes, fraction 2] led to the corresponding product as an off-white powder (38.6 mg, 49\%). Protocol B: from 3,3-bis(4-methoxyphenyl)-1-(p-tolyl)-3H-naphtho[2,1b]pyran 29 (0.50 g, $1.0 \mathrm{mmol})$ after elution from silica gel with DCM (50\%) in hexanes as colourless microcrystals $(0.35 \mathrm{~g}, 70 \%)$. m.p. $=164-165^{\circ} \mathrm{C} ; v_{\max }$ (neat) $2929,2833,1608,1582$, $1507,1461,1244,1175,1033,1004,822,746,569 \mathrm{~cm}^{-1} ;{ }^{1} \mathrm{H}$ NMR $\left(400 \mathrm{MHz}, \mathrm{CDCl}_{3}\right) \delta_{\mathrm{H}} 2.49$ (3H, s, Me), 3.77 (6H, s, OMe), $5.38(1 \mathrm{H}, \mathrm{s}, \alpha-\mathrm{H}), 6.82$ (4H, app. d, $J=8.7 \mathrm{~Hz}, 3^{\prime}, 5^{\prime}, 3^{\prime \prime}, 5^{\prime \prime}-$ H), $7.15\left(4 \mathrm{H}\right.$, app. d, $\left.J=8.7 \mathrm{~Hz}, 2^{\prime}, 6^{\prime}, 2^{\prime \prime}, 6^{\prime \prime}-\mathrm{H}\right), 7.25-7.38(6 \mathrm{H}, \mathrm{m}, \mathrm{Ar}-\mathrm{H}), 7.64(1 \mathrm{H}, \mathrm{d}, J=$ $8.9 \mathrm{~Hz}, 4-\mathrm{H}), 7.69(1 \mathrm{H}, \mathrm{d}, J=8.9 \mathrm{~Hz}, 5-\mathrm{H}), 7.74(1 \mathrm{H}, \mathrm{d}, J=8.3 \mathrm{~Hz}, 9-\mathrm{H}), 7.89(1 \mathrm{H}, \mathrm{d}, J=8.0$ $\mathrm{Hz}, 6-\mathrm{H}) \mathrm{ppm} ;{ }^{13} \mathrm{C}\left\{{ }^{1} \mathrm{H}\right\} \mathrm{NMR}\left(100 \mathrm{MHz}, \mathrm{CDCl}_{3}\right) \delta \mathrm{c} 21.4,46.6,55.2,112.6,113.3,113.8$, $120.0,122.2,123.3,124.1,124.9,125.7,128.2,128.5,128.8,129.5,129.9,130.4,130.71$, 130.74, 134.3, 137.5, 151.9, 154.5, 158.2 ppm; HRMS (ESI) m/z: $[\mathrm{M}+\mathrm{H}]^{+}$Calcd for $\mathrm{C}_{34} \mathrm{H}_{29} \mathrm{O}_{3}{ }^{+}$ 485.2111; Found 485.2105.

\section{Entry 3, Table 3. 4-(2-(Bis(4-methoxyphenyl)methyl)naphtho[2,1-b]furan-5-} yl)morpholine 32. Protocol A: from 3,3-bis(4-methoxyphenyl)-6-morpholino-3Hnaphtho[2,1-b]pyran $31(0.17 \mathrm{~g}, 0.35 \mathrm{mmol})$ after $9 \mathrm{~h}$ of reaction; Flash column

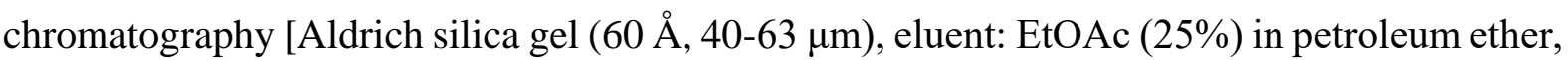
fraction 1] led to the corresponding product as a white powder $(0.13 \mathrm{~g}, 76 \%)$. Protocol B: from 3,3-bis(4-methoxyphenyl)-6-morpholino-3H-naphtho[2,1-b]pyran 31 (1.0 g, $2.1 \mathrm{mmol}$ ) after elution from silica gel with EtOAc $(20 \%)$ in hexanes as an off-white powder $(0.87 \mathrm{~g}, 87 \%)$; 
Flash column chromatography [Aldrich silica gel $(60 \AA, 40-63 \mu \mathrm{m})$, eluent: EtOAc $(25 \%)$ in petroleum ether, fraction 1] led to the corresponding product as a white powder $(0.13 \mathrm{~g}, 76 \%)$. m.p. $=178-180^{\circ} \mathrm{C} ; v_{\max }$ (neat) $2963,1606,1507,1301,1241,1145,1129,1029,801,579,564$ $\mathrm{cm}^{-1} ;{ }^{1} \mathrm{H}$ NMR (400 MHz, $\left.\mathrm{CDCl}_{3}\right) \delta_{\mathrm{H}} 3.02\left(4 \mathrm{H}, \mathrm{bs}, \mathrm{N}\left(\mathrm{CH}_{2}\right) 2\right), 3.73(6 \mathrm{H}, \mathrm{s}, \mathrm{OMe}), 3.92$ (4H, t, $\left.J=4.5 \mathrm{~Hz}, \mathrm{O}\left(\mathrm{CH}_{2}\right)_{2}\right), 5.49(1 \mathrm{H}, \mathrm{s}, \alpha-\mathrm{H}), 6.59(1 \mathrm{H}, \mathrm{s}, 1-\mathrm{H}), 6.80\left(4 \mathrm{H}\right.$, app. d, $J=8.7 \mathrm{~Hz}, 3^{\prime}, 5^{\prime}$, 3", 5"-H), 7.10 (4H, app. d, $\left.J=8.7 \mathrm{~Hz}, 2^{\prime}, 6^{\prime}, 2^{\prime \prime}, 6^{\prime \prime}-\mathrm{H}\right), 7.22(1 \mathrm{H}, \mathrm{s}, 4-\mathrm{H}), 7.38-7.44(2 \mathrm{H}, \mathrm{m}$, Ar-H), $7.93(1 \mathrm{H}, \mathrm{d}, J=7.6 \mathrm{~Hz}, 9-\mathrm{H}), 8.22(1 \mathrm{H}, \mathrm{d}, J=8.1 \mathrm{~Hz}, 6-\mathrm{H}) \mathrm{ppm} ;{ }^{13} \mathrm{C}\left\{{ }^{1} \mathrm{H}\right\} \mathrm{NMR}\left(\mathrm{CDCl}_{3}\right)$ $\delta_{\mathrm{C}} 48.8,52.8,54.2,66.4,101.5,103.1,112.9,118.7,123.0,123.4,125.0,125.3,127.2,128.8$, 132.7, 146.1, 151.5, 157.5, 158.2 ppm; HRMS (ESI) m/z: $[\mathrm{M}+\mathrm{H}]^{+}$Calcd for $\mathrm{C}_{31} \mathrm{H}_{30} \mathrm{NO}_{4}{ }^{+}$ 480.2169; Found 480.2169.

Entry 4, Table 3. 2-((4-Methoxyphenyl)(thiophen-2-yl)methyl)naphtho[2,1-b]furan 34.

Protocol B: from 3-(4-methoxyphenyl)-3-(thiophen-2-yl)-3H-naphtho[2,1-b]pyran 33 (1.0 g, $2.7 \mathrm{mmol})$ after elution from $\mathrm{SiO}_{2}$ with EtOAc (20\%) in hexanes as an off-white powder (0.63 g, 63\%). m.p. $=158-160{ }^{\circ} \mathrm{C} ; v_{\max }$ (neat) 2955, 2930, 2834, 1608, 1586, 1509, 1463, 1441, 1383, 1249, 1109, 1030, 991, 954, 854, 804, 774, 744, 718, 559, $530.0 \mathrm{~cm}^{-1} ;{ }^{1} \mathrm{H}$ NMR (400 MHz, $\left.\mathrm{CDCl}_{3}\right) \delta_{\mathrm{H}} 3.83(3 \mathrm{H}, \mathrm{s}, \mathrm{OMe}), 5.87(1 \mathrm{H}, \mathrm{s}, \alpha-\mathrm{H}), 6.92-6.95(4 \mathrm{H}, \mathrm{m}, \mathrm{Ar}-\mathrm{H}), 7.02(1 \mathrm{H}$, app. t, $J=3.7 \mathrm{~Hz}, \mathrm{Ar}-\mathrm{H}), 7.28-7.34(3 \mathrm{H}, \mathrm{m}, \mathrm{Ar}-\mathrm{H}), 7.49$ (1H, app. t, $J=7.6 \mathrm{~Hz}, \mathrm{Ar}-\mathrm{H}), 7.57(1 \mathrm{H}$, app. t, $J=7.2 \mathrm{~Hz}, \mathrm{Ar}-\mathrm{H}), 7.62(1 \mathrm{H}, \mathrm{d}, J=8.9 \mathrm{~Hz}, 4-\mathrm{H}), 7.70(1 \mathrm{H}, \mathrm{d}, J=8.9 \mathrm{~Hz}, 5-\mathrm{H}), 7.95$ $(1 \mathrm{H}, \mathrm{d}, J=8.0 \mathrm{~Hz}, 6-\mathrm{H}), 8.07(1 \mathrm{H}, \mathrm{d}, J=8.1 \mathrm{~Hz}, 9-\mathrm{H}) ;{ }^{13} \mathrm{C}\left\{{ }^{1} \mathrm{H}\right\} \mathrm{NMR}\left(400 \mathrm{MHz}, \mathrm{CDCl}_{3}\right) \delta \mathrm{C}$ $46.0,55.3,104.0,112.4,114.1,123.49,123.51,124.4,124.8,124.9,126.2,126.8,127.6,128.8$, 129.6, 130.3, 133.2, 145.1, 152.5, 158.86, 158.90; HRMS (ESI) m/z: $[\mathrm{M}+\mathrm{H}]^{+}$Calcd for $\mathrm{C}_{24} \mathrm{H}_{19} \mathrm{O}_{2} \mathrm{~S}^{+}$371.1100; Found 371.1104.

Entry 5, Table 3. 2,9-Bis(bis(4-methoxyphenyl)methyl)naphtho[2,1-b:7,8- $\left.b^{\prime}\right]$ difuran 36.

Protocol A: from 3,3,10,10-tetrakis(4-methoxyphenyl)-3,10-dihydrochromeno[5,6- 
$f$ chromene $35(0.50 \mathrm{~g}, 0.76 \mathrm{mmol})$ after $9 \mathrm{~h}$ of reaction; brown powder $(0.44 \mathrm{~g}, 88 \%)$. Protocol B: from 3,3,10,10-tetrakis(4-methoxyphenyl)-3,10-dihydrochromeno[5,6-f]chromene 35 (0.5 g, $0.8 \mathrm{mmol}$ ) after elution from $\mathrm{SiO}_{2}$ with EtOAc (25\%) in hexanes as an off-white powder $(0.48$ g, $96 \%)$. m.p. $=160-162{ }^{\circ} \mathrm{C} ; v_{\max }$ (neat) $2927,2833,1609,1507,1301,1248,1173,1024$, 810, 770, $567 \mathrm{~cm}^{-1} ;{ }^{1} \mathrm{H}$ NMR (400 MHz, $\left.\mathrm{CDCl}_{3}\right) \delta_{\mathrm{H}} 3.79(12 \mathrm{H}, \mathrm{s}, \mathrm{OMe}), 5.59(2 \mathrm{H}, \mathrm{s}, \alpha, \beta-\mathrm{H})$, $6.79(2 \mathrm{H}, \mathrm{s}, 1,10-\mathrm{H}), 6.86\left(8 \mathrm{H}\right.$, app. d, $\left.J=8.7 \mathrm{~Hz}, 3^{\prime}, 5^{\prime}, 3^{\prime \prime}, 5^{\prime \prime}, 3^{\prime \prime \prime}, 5^{\prime \prime \prime}, 3^{\prime \prime \prime \prime}, 5^{\prime \prime \prime \prime}-\mathrm{H}\right), 7.17(8 \mathrm{H}$, app. d, $\left.J=8.7 \mathrm{~Hz}, 2^{\prime}, 6^{\prime}, 2^{\prime \prime}, 6^{\prime \prime}, 2^{\prime \prime \prime}, 6^{\prime \prime \prime}, 2^{\prime \prime \prime \prime}, 6^{\prime \prime \prime \prime}-\mathrm{H}\right), 7.55(2 \mathrm{H}, \mathrm{d}, J=8.9 \mathrm{~Hz}, 5,6-\mathrm{H}), 7.74$ $(2 \mathrm{H}, \mathrm{d}, J=8.9 \mathrm{~Hz}, 4,7-\mathrm{H}) \mathrm{ppm} ;{ }^{13} \mathrm{C}\left\{{ }^{1} \mathrm{H}\right\} \mathrm{NMR}\left(100 \mathrm{MHz}, \mathrm{CDCl}_{3}\right) \delta_{\mathrm{C}} 49.8,55.3,105.3,110.5$, 114.0, 121.5, 122.0, 125.4, 127.0, 129.8, 133.8, 153.2, 158.5, 159.5 ppm; HRMS (ESI) m/z: $[\mathrm{M}+\mathrm{H}]^{+}$Calcd for $\mathrm{C}_{44} \mathrm{H}_{37} \mathrm{O}_{6}{ }^{+}$661.2585; Found 661.2553.

Entry 6, Table 3. 2,9-Bis(bis(4-methoxyphenyl)methyl)naphtho[2,1-b:3,4-b']difuran 38 .

Protocol A: from 2,2,11,11-tetrakis(4-methoxyphenyl)-2,11-dihydrobenzo[f]pyrano[3,2$h$ chromene $37(0.50 \mathrm{~g}, 0.76 \mathrm{mmol})$ after $9 \mathrm{~h}$ of reaction; Crystallization from a mixture of $\mathrm{DCM} /$ hexane led to the corresponding product as a brown crystalline powder $(0.24 \mathrm{~g}, 48 \%)$.

Protocol B: from 2,2,11,11-tetrakis(4-methoxyphenyl)-2,11-dihydrobenzo[f]pyrano[3,2$h$ chromene $37(0.5 \mathrm{~g}, 0.8 \mathrm{mmol})$ after elution from $\mathrm{SiO}_{2}$ with EtOAc $(20 \%)$ in hexanes as an off-white powder $(0.10 \mathrm{~g}, 20 \%)$. m.p. $=184-188^{\circ} \mathrm{C}\left(\right.$ darkened at $\left.141^{\circ} \mathrm{C}\right)$; $v_{\max }($ neat $) 2930$, $2833,1606,1582,1508,1440,1238,1175,1110,1028,815,760,556 \mathrm{~cm}^{-1} ;{ }^{1} \mathrm{H}$ NMR (400 $\left.\mathrm{MHz}_{\mathrm{CDCl}}\right) \delta_{\mathrm{H}} 3.80(12 \mathrm{H}, \mathrm{s}, \mathrm{OMe}), 5.60(2 \mathrm{H}, \mathrm{s}, \alpha, \beta-\mathrm{H}), 6.75(2 \mathrm{H}, \mathrm{s}, 3,8-\mathrm{H}), 6.86(8 \mathrm{H}$, app. $\left.\mathrm{d}, J=8.6 \mathrm{~Hz}, 3^{\prime}, 5^{\prime}, 3^{\prime \prime}, 5^{\prime \prime}, 3^{\prime \prime \prime}, 5^{\prime \prime \prime}, 3^{\prime \prime \prime \prime}, 5^{\prime \prime \prime \prime}-\mathrm{H}\right), 7.16\left(8 \mathrm{H}\right.$, app. d, $J=8.6 \mathrm{~Hz}, 2^{\prime}, 6^{\prime}, 2^{\prime \prime}, 6^{\prime \prime}, 2^{\prime \prime \prime}$, $\left.6^{\prime \prime \prime}, 2^{\prime \prime \prime \prime}, 66^{\prime \prime \prime \prime}-\mathrm{H}\right), 7.46-7.49(2 \mathrm{H}, \mathrm{m}, 5,6-\mathrm{H}), 8.03-8.05(2 \mathrm{H}, \mathrm{m}, 4,7-\mathrm{H}) \mathrm{ppm} ;{ }^{13} \mathrm{C}\left\{{ }^{1} \mathrm{H}\right\} \mathrm{NMR}$ $\left(100 \mathrm{MHz}, \mathrm{CDCl}_{3}\right) \delta_{\mathrm{C}} 49.8,55.3,105.2,114.0,122.2,124.1,124.7,124.9,129.8,133.7,139.5$, 158.5, 159.4 ppm; HRMS (ESI) m/z: $[\mathrm{M}+\mathrm{K}]^{+}$Calcd for $\mathrm{C}_{44} \mathrm{H}_{36} \mathrm{O}_{6} \mathrm{~K}^{+}$699.2143; Found 699.2135 . 
Entry 7, Table 3. 2,7-Bis(bis(4-methoxyphenyl)methyl)naphtho[2,1-b:6,5-b']difuran 40.

Protocol A: from 2,2,8,8-tetrakis(4-methoxyphenyl)-2,8-dihydrochromeno[6,5-f]chromene 39 $(0.50 \mathrm{~g}, 0.76 \mathrm{mmol})$ after $21 \mathrm{~h}$ of reaction; After the reaction was completed, the crude was evaporated to dryness. Afterwards, PhMe (200 mL) was added and the resulting mixture filtered hot. The resulting filtrand was poured into water $(50 \mathrm{~mL})$, filtered off, rinsed with water $(100 \mathrm{~mL})$, cold $\mathrm{PhMe}(15 \mathrm{~mL})$ and cold $\mathrm{Et}_{2} \mathrm{O}(5 \mathrm{~mL})$ giving the corresponding product as an off-white powder $(0.16 \mathrm{~g}, 32 \%)$. The former filtrate was reduced and the solid filtered off, rinsed with water $(100 \mathrm{~mL})$, cold $\mathrm{PhMe}(15 \mathrm{~mL})$ and cold $\mathrm{Et}_{2} \mathrm{O}(5 \mathrm{~mL})$ giving the corresponding product as an off-white powder $(0.21 \mathrm{~g}, 42 \%)$. m.p. $=279-282{ }^{\circ} \mathrm{C}\left(\right.$ darkened at $\left.264{ }^{\circ} \mathrm{C}\right) ; v_{\max }$ (neat) $2834,1606,1508,1239,1175,1156,1033,816,571 \mathrm{~cm}^{-1} ;{ }^{1} \mathrm{H}$ NMR (400 MHz, DMSOd6) $\delta_{\mathrm{H}} 3.74(12 \mathrm{H}, \mathrm{s}, \mathrm{OMe}), 5.7$ (2H, s, $\left.\alpha, \beta-\mathrm{H}\right), 6.93$ (8H, app. d, $\left.J=8.7 \mathrm{~Hz}, \mathrm{Ar}-\mathrm{H}\right), 7.08(2 \mathrm{H}$, s, 1, 6-H), $7.22(8 \mathrm{H}$, app. d, $J=8.7 \mathrm{~Hz}, \mathrm{Ar}-\mathrm{H}), 7.74(2 \mathrm{H}, \mathrm{d}, J=9.0 \mathrm{~Hz}, \mathrm{Ar}-\mathrm{H}), 8.08(2 \mathrm{H}, \mathrm{d}, J=$ $9.0 \mathrm{~Hz}, \mathrm{Ar}-\mathrm{H}) \mathrm{ppm} ;{ }^{13} \mathrm{C}\left\{{ }^{1} \mathrm{H}\right\} \mathrm{NMR}\left(100 \mathrm{MHz}, \mathrm{DMSO}-\mathrm{d}_{6}\right) \div \delta_{\mathrm{C}} 49.2,55.5,104.5,112.5,114.4$, 120.6, 124.2, 124.6, 130.0, 134.0, 151.4, 158.4, 160.5 ppm; HRMS (ESI) m/z: $[\mathrm{M}+\mathrm{K}]^{+}$Calcd for $\mathrm{C}_{44} \mathrm{H}_{36} \mathrm{O}_{6} \mathrm{~K}^{+}$699.2143; Found 699.2144.

${ }^{4}$ Due to the low solubility of the compound, the ${ }^{13} \mathrm{C}$ NMR peaks were inferred from HSQC and HMBC analysis.

\section{Entry 8, Table 3. 4-(2-(Bis(4-methoxyphenyl)methyl)-3-phenyl-3H-benzo[e]indol-5-} yl)morpholine 42. Protocol A: from 4-(3,3,4-tris(4-methoxyphenyl)-3,4dihydrobenzo[f]quinolin-6-yl)morpholine 41 (0.50 g, $0.86 \mathrm{mmol})$ after 9 days of reaction; The residue was crystallized from a mixture of DCM/hexane giving the corresponding product as an off-white crystalline solid $(0.28 \mathrm{~g}, 56 \%)$; The resulting mother-liquor was purified by flash

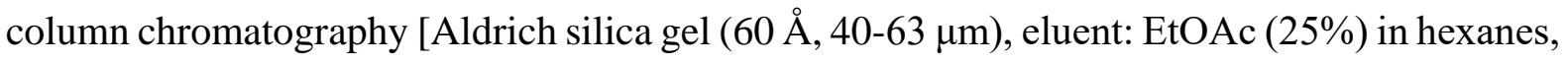
fraction 2] giving the corresponding product as a beige powder $(0.12 \mathrm{~g}, 24 \%)$; m.p. $=215-217$ 
${ }^{\circ} \mathrm{C} ; v_{\max }\left(\right.$ neat) $2969,1508,1457,1358,1244,1174,1114,1035,842,760 \mathrm{~cm}^{-1} ;{ }^{1} \mathrm{H}$ NMR (400 $\left.\mathrm{MHz}, \mathrm{CDCl}_{3}\right) \delta_{\mathrm{H}} 2.98\left(4 \mathrm{H}, \mathrm{bs}, \mathrm{N}\left(\mathrm{CH}_{2}\right)_{2}\right), 3.78$ (6H, s, OMe), $3.86\left(3 \mathrm{H}, \mathrm{s}, 4^{\prime \prime \prime}-\mathrm{OMe}\right), 3.92(4 \mathrm{H}$, t, $\left.J=4.5 \mathrm{~Hz}, \mathrm{O}\left(\mathrm{CH}_{2}\right)_{2}\right), 5.27(1 \mathrm{H}, \mathrm{s}, \alpha-\mathrm{H}), 6.56(1 \mathrm{H}, \mathrm{s}, 1-\mathrm{H}), 6.76-6.79(5 \mathrm{H}, \mathrm{m}, \mathrm{Ar}-\mathrm{H}), 6.88-$ $6.90(2 \mathrm{H}, \mathrm{m}, \mathrm{Ar}-\mathrm{H}), 6.99$ (6H, app. d, $J=8.6 \mathrm{~Hz}, \mathrm{Ar}-\mathrm{H}), 7.37-7.41(1 \mathrm{H}, \mathrm{m}, 7-\mathrm{H}), 7.46-7.50$ $(1 \mathrm{H}, \mathrm{m}, 8-\mathrm{H}), 8.13(1 \mathrm{H}$, app. d, $J=7.7 \mathrm{~Hz}, 9-\mathrm{H}), 8.26(1 \mathrm{H}$, app. d, $J=8.3 \mathrm{~Hz}, 6-\mathrm{H}) \mathrm{ppm}$; ${ }^{13} \mathrm{C}\left\{{ }^{1} \mathrm{H}\right\} \mathrm{NMR}\left(100 \mathrm{MHz}, \mathrm{CDCl}_{3}\right) \delta_{\mathrm{C}} 48.1,53.9,55.3,55.5,67.6,101.7,101.9,113.6,114.4$, $119.1,123.0,123.6,124.2,125.3,125.8,128.6,129.9,130.0,130.1,134.9,135.1,142.2,145.2$, 158.1, 159.2 ppm; HRMS (ESI) m/z: $[\mathrm{M}+\mathrm{H}]^{+}$Calcd for $\mathrm{C}_{38} \mathrm{H}_{37} \mathrm{~N}_{2} \mathrm{O}_{4}{ }^{+}$585.2748; Found 585.2748 .

Entry 1, Table 4. 2-(Bis(4-methoxyphenyl)methyl)-5-methoxynaphtho[1,2-b]furan 46.

Protocol A: from 6-methoxy-2,2-bis(4-methoxyphenyl)-2H-naphtho[1,2-b]pyran 45 (185.5 $\mathrm{mg}, 0.4370 \mathrm{mmol}$ ) after $9 \mathrm{~h}$ of reaction; Purification by preparative TLC [Merck Silica gel 60 F254, eluent: EtOAc (10\%) in hexanes, fraction 1] led to the corresponding product as an offwhite powder $(34.9 \mathrm{mg}, 19 \%)$. m.p. $=115-118^{\circ} \mathrm{C}$; $v_{\max }$ (neat) $2926,2834,1607,1588,1508$, 1456, 1378, 1240, 1176, 1032, 830, 770, $549 \mathrm{~cm}^{-1} ;{ }^{1} \mathrm{H}$ NMR (400 MHz, $\left.\mathrm{CDCl}_{3}\right) \delta_{\mathrm{H}} 3.79(6 \mathrm{H}$, s, OMe), 3.98 (3H, s, 5-OMe), $5.59(1 \mathrm{H}, \mathrm{s}, \alpha-\mathrm{H}), 6.31(1 \mathrm{H}, \mathrm{d}, J=0.9 \mathrm{~Hz}, 3-\mathrm{H}), 6.83-6.87(5 \mathrm{H}$, m, Ar-H), 7.14-7.17 (4H, m, Ar-H), 7.41-7.45 (1H, m, 7-H), 7.51-7.55 (1H, m, 8-H), 8.13 (1H, app. d, $J=7.9 \mathrm{~Hz}, 9-\mathrm{H}), 8.28(1 \mathrm{H}$, app. d, $J=8.3 \mathrm{~Hz}, 6-\mathrm{H}) \mathrm{ppm} ;{ }^{13} \mathrm{C}\left\{{ }^{1} \mathrm{H}\right\} \mathrm{NMR}(100$ $\left.\mathrm{MHz}, \mathrm{CDCl}_{3}\right) \delta_{\mathrm{C}} 49.8,55.3,55.9,96.9,106.6,113.9,119.8,121.7,122.9,123.2,123.6,124.2$, 126.7, 129.8, 134.1, 145.3, 152.0, 158.4, 159.7 ppm; HRMS (ESI) m/z: $[\mathrm{M}+\mathrm{H}]^{+}$Calcd for $\mathrm{C}_{28} \mathrm{H}_{25} \mathrm{O}_{4}{ }^{+} 425.1747 ;$ Found 425.1749 .

Entry 2, Table 4. 2-(Bis(4-methoxyphenyl)methyl)-5-methoxy-3-(p-tolyl)naphtho[1,2b]furan 48. Protocol A: from 6-methoxy-2,2-bis(4-methoxyphenyl)-4-(p-tolyl)-2Hnaphtho[1,2-b]pyran $47(0.50 \mathrm{~g}, 0.97 \mathrm{mmol})$ after $25 \mathrm{~h}$ of reaction; Purification by flash column 


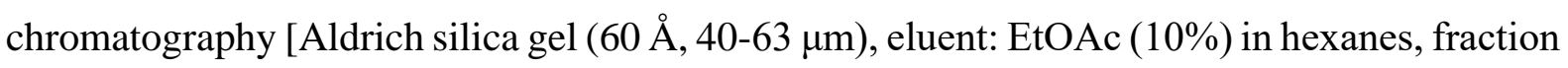
1] gave the corresponding product as an off-white powder $(0.17 \mathrm{~g}, 34 \%)$. Protocol B: from 6methoxy-2,2-bis(4-methoxyphenyl)-4-(p-tolyl)-2H-naphtho[1,2-b]pyran $47 \quad(0.50 \quad \mathrm{~g}, \quad 0.97$ mmol) after $22 \mathrm{~h}$ of reaction; The residue was purified by flash column chromatography

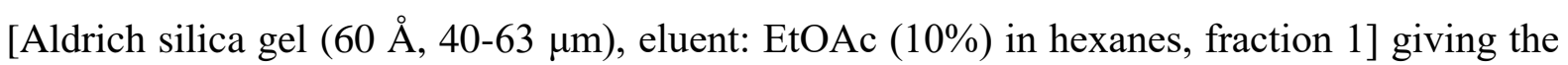
corresponding product as an off-white powder $(0.10 \mathrm{~g}, 20 \%) . \mathrm{m} . \mathrm{p} .=196-200{ }^{\circ} \mathrm{C} ; v_{\max }$ (neat) $2926,2832,1610,1585,1507,1459,1376,1247,1173,1034,831,765,515 \mathrm{~cm}^{-1} ;{ }^{1} \mathrm{H}$ NMR

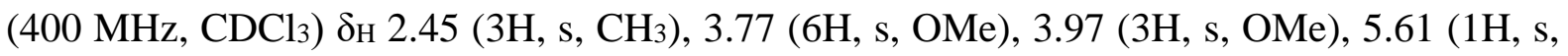
$\alpha-\mathrm{H}), 6.83$ (4H, app. d, $\left.J=8.7 \mathrm{~Hz}, 3^{\prime}, 3^{\prime \prime}, 5^{\prime}, 5^{\prime \prime}-\mathrm{H}\right), 6.91(1 \mathrm{H}, \mathrm{s}, 4-\mathrm{H}), 7.23$ (4H, app. d, $J=8.7$ Hz, 2', 6', 2", 6"-H), 7.32 (2H, app. d, $J=7.9 \mathrm{~Hz}, \mathrm{Ar}-\mathrm{H}), 7.40$ (2H, app. d, $J=7.9 \mathrm{~Hz}, \mathrm{Ar}-\mathrm{H})$, 7.43-7.47 (1H, m, Ar-H), 7.54-7.58 (1H, m, Ar-H), 8.19 (1H, app. d, J= 7.9 Hz, 9-H), 8.29 $(1 \mathrm{H}$, app. d, $J=8.3 \mathrm{~Hz}, 6-\mathrm{H}) \mathrm{ppm} ;{ }^{13} \mathrm{C}\left\{{ }^{1} \mathrm{H}\right\} \mathrm{NMR}\left(76 \mathrm{MHz}, \mathrm{CDCl}_{3}\right) \delta_{\mathrm{C}} 21.3,47.2,55.3,56.0$, $95.9,113.8,119.6,119.9,121.7,123.0,123.2,123.9,124.4,126.8,129.2,129.6,129.8,130.0$, 134.6, 137.1, 144.8, 152.3, 153.5, 158.3 ppm; HRMS (ESI) m/z: $[\mathrm{M}+\mathrm{H}]^{+}$Calcd for $\mathrm{C}_{35} \mathrm{H}_{31} \mathrm{O}_{4}{ }^{+}$ 515.2217; Found 515.2207.

\section{Entry 3, Table 4. (5-(Bis(4-methoxyphenyl)methyl)naphtho[1,2-b:4,3-b']difuran-3-} yl)(phenyl)methanone 50. Protocol A: from (6,6-bis(4-methoxyphenyl)-6Hbenzo[h]furo[3,2-f]chromen-3-yl)(phenyl)methanone $49(208.0 \mathrm{mg}, 0.3862 \mathrm{mmol})$ after $14 \mathrm{~h}$ of reaction $-\mathrm{Pd}(\mathrm{OAc})_{2}(4 \mathrm{~mol} \%)$ was added to the reaction mixture. Purification by flash

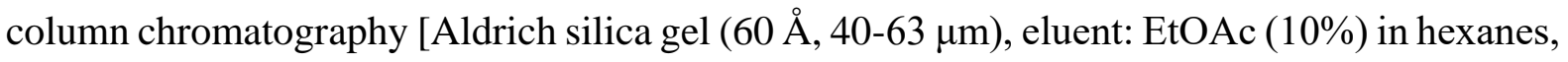
fraction 1], followed by trituration from hexanes, gave the corresponding product as an offwhite powder $(92.1 \mathrm{mg}, 44 \%)$. Protocol B: from (6,6-bis(4-methoxyphenyl)-6Hbenzo[h]furo[3,2-f]chromen-3-yl)(phenyl)methanone 49 (139.5 mg, $0.2590 \mathrm{mmol})$ after $14 \mathrm{~h}$ of reaction. Flash column chromatography [Aldrich silica gel (60 Å, 40-63 $\mu \mathrm{m})$, eluent: EtOAc 
$(10 \%)$ in petroleum ether, fraction 1] led to the corresponding product as a not entirely pure pale-yellow powder $(15.5 \mathrm{mg},<11 \%)$. m.p. $=188-190^{\circ} \mathrm{C} ; v_{\max }$ (neat) $1653,1508,1244,1180$, $1171,1148,1107,1034,880,771,674,560 \mathrm{~cm}^{-1} ;{ }^{1} \mathrm{H} \mathrm{NMR}\left(400 \mathrm{MHz}, \mathrm{CDCl}_{3}\right) \delta_{\mathrm{H}} 3.80(6 \mathrm{H}, \mathrm{s}$, OMe), $5.66(1 \mathrm{H}, \mathrm{s}, \alpha-\mathrm{H}), 6.86\left(4 \mathrm{H}\right.$, app. d, $\left.J=8.6 \mathrm{~Hz}, 3^{\prime}, 3^{\prime \prime}, 5^{\prime}, 5^{\prime \prime}-\mathrm{H}\right), 7.07$ (1H, s, 3-H), 7.20 (4H, app. d, $\left.J=8.6 \mathrm{~Hz}, 2^{\prime}, 2^{\prime \prime}, 6^{\prime}, 6^{\prime \prime}-\mathrm{H}\right), 7.50-7.64(5 \mathrm{H}, \mathrm{m}, \mathrm{Ar}-\mathrm{H}), 7.92(2 \mathrm{H}, \mathrm{d}, J=7.2 \mathrm{~Hz}$, Ar-H), $8.20(1 \mathrm{H}, \mathrm{s}, 5-\mathrm{H}), 8.30-8.36(2 \mathrm{H}, \mathrm{m}, \mathrm{Ar}-\mathrm{H}) \mathrm{ppm} ;{ }^{13} \mathrm{C}\left\{{ }^{1} \mathrm{H}\right\}$ NMR $\left(100 \mathrm{MHz}, \mathrm{CDCl}_{3}\right)$ $\delta_{\mathrm{C}} 49.9,55.3,107.8,113.9,115.1,118.0,118.3,119.9,120.7,120.9,123.3,125.5,126.2,128.7$, 129.0, 129.8, 132.6, 134.0, 139.3, 148.3, 148.7, 151.1, 158.4, 159.6, 190.3 ppm; HRMS (ESI) m/z: $[\mathrm{M}+\mathrm{H}]^{+}$Calcd for $\mathrm{C}_{36} \mathrm{H}_{27} \mathrm{O}_{5}{ }^{+}$539.1858; Found 539.1851 .

\section{Entry 4, Table 4. (5-(Bis(4-methoxyphenyl)methyl)-4-(p-tolyl)naphtho[1,2-b:4,3-} b']difuran-3-yl)(phenyl)methanone 52. Protocol A: from (6,6-bis(4-methoxyphenyl)-4-( $p$ tolyl)-6H-benzo[h]furo[3,2-f]chromen-3-yl)(phenyl)methanone $51(0.30 \mathrm{~g}, 0.48 \mathrm{mmol})$ after $14 \mathrm{~h}$ of reaction $-\mathrm{Pd}(\mathrm{OAc})_{2}(4 \mathrm{~mol} \%)$ was added to the reaction mixture. Purification by flash column chromatography [Aldrich silica gel $(60 \AA, 40-63 \mu \mathrm{m})$, eluent: EtOAc $(10 \%)$ in petroleum ether, fraction 1], followed by crystallization from EtOAc (10\%) in petroleum ether, led to the corresponding product as an off-white powder $(0.14 \mathrm{~g}, 47 \%)$. Protocol B: from $(6,6-$ bis(4-methoxyphenyl)-4-(p-tolyl)-6H-benzo[h]furo[3,2-f]chromen-3-yl)(phenyl)methanone $51(0.30 \mathrm{~g}, 0.48 \mathrm{mmol})$ after $14 \mathrm{~h}$ of reaction. Purification by flash column chromatography [Aldrich silica gel (60 $\mathrm{A}, 40-63 \mu \mathrm{m})$, eluent: EtOAc (10\%) in petroleum ether, fraction 1], followed by crystallization from EtOAc (10\%) in petroleum ether, led to the corresponding product as a not entirely pure pale-yellow powder $(0.01 \mathrm{~g},<3 \%)$. m.p. $=195-197{ }^{\circ} \mathrm{C}$; $v_{\max }$ (neat) $1654,1601,1506,1455,1245,1231,1174,1029,886,767,689,557 \mathrm{~cm}^{-1}$; ${ }^{1} \mathrm{H}$ NMR (400 $\left.\mathrm{MHz}, \mathrm{CDCl}_{3}\right) \delta_{\mathrm{H}} 2.30\left(3 \mathrm{H}, \mathrm{s}, \mathrm{CH}_{3}\right), 3.78(6 \mathrm{H}, \mathrm{s}, \mathrm{OMe}), 5.41(1 \mathrm{H}, \mathrm{s}, \alpha-\mathrm{H}), 6.79-6.86(8 \mathrm{H}, \mathrm{m}$, Ar-H), $7.15-7.21(6 \mathrm{H}, \mathrm{m}, \mathrm{Ar}-\mathrm{H}), 7.39(1 \mathrm{H}, \mathrm{t}, J=7.4 \mathrm{~Hz}, \mathrm{Ar}-\mathrm{H}), 7.45(1 \mathrm{H}, \mathrm{d}, J=7.5 \mathrm{~Hz}, \mathrm{Ar}-$ 
H), $7.60-7.64(2 \mathrm{H}, \mathrm{m}, \mathrm{Ar}-\mathrm{H}), 8.02(1 \mathrm{H}, \mathrm{s}, 5-\mathrm{H}), 8.33-8.36(1 \mathrm{H}, \mathrm{m}, \mathrm{Ar}-\mathrm{H}), 8.38-8.41(1 \mathrm{H}$, $\mathrm{m}, \mathrm{Ar}-\mathrm{H}) \mathrm{ppm} ;{ }^{13} \mathrm{C}\left\{{ }^{1} \mathrm{H}\right\} \mathrm{NMR}\left(100 \mathrm{MHz}, \mathrm{CDCl}_{3}\right) \delta_{\mathrm{C}} 21.2,46.7,55.2,113.8,114.5,117.2$, $118.8,119.8,120.1,120.9,123.8,125.7,126.2,127.7,128.7,129.5,129.6,129.8,129.9,132.7$, 134.4, 136.6, 136.9 146.1, 147.6, 148.6, 154.3, 158.3, 189.4 ppm; HRMS (ESI) m/z: $[\mathrm{M}+\mathrm{H}]^{+}$ Calcd for $\mathrm{C}_{43} \mathrm{H}_{33} \mathrm{O}_{5}^{+}$629.2328; Found 629.2331.

\section{Experimental Procedure for the Synthesis of 4-(2-(bis(4-} methoxyphenyl)methyl)naphtho[2,1-b]furan-7-yl)pyridine 55: a mixture of 8-bromo-3,3bis(4-methoxyphenyl)-3H-naphtho[2,1-b]pyran $\quad \mathbf{5 3} \quad(200.1 \quad \mathrm{mg}, \quad 0.4227 \quad \mathrm{mmol}), \quad 4-$ pyridineboronic acid pinacol ester 54 (129.9 mg, $0.6335 \mathrm{mmol}), \mathrm{K}_{2} \mathrm{CO}_{3}(87.6 \mathrm{mg}, 0.634 \mathrm{mmol})$, 18-crown-6 (347.0 mg, $1.313 \mathrm{mmol})$ and $\mathrm{Pd}\left(\mathrm{PPh}_{3}\right)_{4}(24.8 \mathrm{mg}, 0.0215 \mathrm{mmol})$ in $\mathrm{PhMe}(10.0$ $\mathrm{mL}$ ) was heated at reflux under $\mathrm{N}_{2}$ for $19 \mathrm{~h}$. After this time, the mixture was cooled and poured into water $(100 \mathrm{~mL})$. Afterwards, the residue was extracted with DCM $(3 \times 100 \mathrm{~mL})$, washed with water $(3 \times 150 \mathrm{~mL})$, the organic layer dried over anhydrous sodium sulphate and the solvent removed under reduced pressure. Flash column chromatography [Fluorochem silica gel (60 ̊, 40-63 $\mu \mathrm{m}$ ), eluent: $\mathrm{MeOH}(4 \%)$ in DCM, fraction 5], followed by trituration with ethylic ether, led to the corresponding product as a yellow powder.

2-(Bis(4-methoxyphenyl)methyl)-7-(4-pyridyl)naphtho[2,1-b]furan 55. Yellow powder (93.8 mg, 47\%); m.p. $=168-172{ }^{\circ} \mathrm{C} ; v_{\max }$ (neat) 1594, 1507, 1462, 1301, 1244, 1174, 1031, 994, 805, 727, $586 \mathrm{~cm}^{-1} ;{ }^{1} \mathrm{H}$ NMR (400 MHz, $\left.\mathrm{CDCl}_{3}\right) \delta_{\mathrm{H}} 3.81$ (s, 6H, OMe), $5.61(\mathrm{~s}, 1 \mathrm{H}, \alpha-\mathrm{H})$, 6.75 (s, 1H, 1-H), 6.90 (app. d, 4H, $J=8.6 \mathrm{~Hz}, 3^{\prime}, 5^{\prime}, 3^{\prime \prime}, 5^{\prime \prime}-\mathrm{H}$ ), 7.18 (app. d, 4H, $J=8.6 \mathrm{~Hz}$, $\left.2^{\prime}, 6^{\prime}, 2^{\prime \prime}, 6^{\prime \prime}-\mathrm{H}\right), 7.63-7.66\left(\mathrm{~m}, 3 \mathrm{H}, 4,2^{\prime \prime \prime}, 6^{\prime \prime \prime}-\mathrm{H}\right), 7.74(\mathrm{~d}, 1 \mathrm{H}, J=8.9 \mathrm{~Hz}, 5-\mathrm{H}), 7.79$ (dd, 1H, $J=8.5,1.5 \mathrm{~Hz}, 8-\mathrm{H}), 8.12(\mathrm{~d}, 1 \mathrm{H}, J=8.5 \mathrm{~Hz}, 9-\mathrm{H}), 8.20$ (app. s, 1H, 6-H), 8.69 (d, 2H, $J=4.7$ $\left.\mathrm{Hz}, 3^{\prime \prime \prime}, 5^{\prime \prime \prime}-\mathrm{H}\right) \mathrm{ppm} ;{ }^{13} \mathrm{C}\left\{{ }^{1} \mathrm{H}\right\} \mathrm{NMR}\left(100 \mathrm{MHz}, \mathrm{CDCl}_{3}\right) \delta_{\mathrm{C}} 49.9,55.3,104.4,113.3,114.0$, $121.8,123.6,124.57,124.64,124.9,127.3,127.7,129.8,130.4,133.5,133.8,148.6,150.1$, 
153.0, 158.6, 160.6 ppm; HRMS (ESI) m/z: $[\mathrm{M}+\mathrm{H}]^{+}$Calcd for $\mathrm{C}_{32} \mathrm{H}_{26} \mathrm{NO}_{3}{ }^{+}$472.1907; Found 472.1908.

Experimental Procedure for the Synthesis of 3,3-Bis(4-methoxyphenyl)-8-(4-pyridyl)-3Hnaphtho[2,1-b]pyran 56 using KF (1.5 equiv): a mixture of 8-bromo-3,3-bis(4methoxyphenyl)-3H-naphtho[2,1-b]pyran 53 (200.0 mg, $0.4225 \mathrm{mmol}$ ), 4-pyridineboronic acid pinacol ester $54(129.7 \mathrm{mg}, 0.6325 \mathrm{mmol}), \mathrm{KF}(37.0 \mathrm{mg}, 0.637 \mathrm{mmol})$ and $\mathrm{Pd}\left(\mathrm{PPh}_{3}\right)_{4}(24.5$ $\mathrm{mg}, 0.0212 \mathrm{mmol})$ in PhMe $(5.0 \mathrm{~mL})$ and ethanol $(5.0 \mathrm{~mL})$ was heated at reflux under $\mathrm{N}_{2}$ for 15h. After this time, the mixture was evaporated to dryness. Afterwards, the residue was extracted with DCM $(3 \times 100 \mathrm{~mL})$, washed with water $(3 \times 150 \mathrm{~mL})$, the organic layer dried over anhydrous sodium sulphate and the solvent removed under reduced pressure. Flash

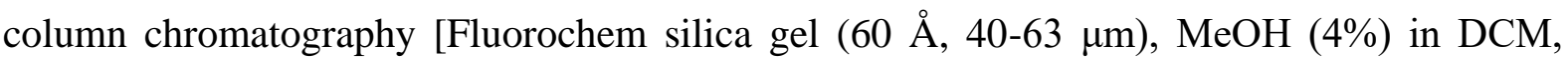
fraction 2], followed by trituration with diethyl ether, led to the corresponding product as a white powder.

Experimental Procedure for the Synthesis of 3,3-Bis(4-methoxyphenyl)-8-(4-pyridyl)-3Hnaphtho[2,1-b]pyran 56 using KF (3.0 equiv): a mixture of 8-bromo-3,3-bis(4methoxyphenyl)-3H-naphtho[2,1-b]pyran 53 (101.3 mg, $0.2140 \mathrm{mmol})$, 4-pyridineboronic acid pinacol ester $54(64.6 \mathrm{mg}, 0.315 \mathrm{mmol}), \mathrm{KF}(36.8 \mathrm{mg}, 0.633 \mathrm{mmol})$ and $\mathrm{Pd}\left(\mathrm{PPh}_{3}\right)_{4}(12.6$ $\mathrm{mg}, 0.0109 \mathrm{mmol})$ in $\mathrm{PhMe}(2.0 \mathrm{~mL})$ and ethanol $(2.0 \mathrm{~mL})$ was heated at reflux under $\mathrm{N}_{2}$ for 13h. After this time, the mixture was evaporated to dryness. Afterwards, the residue was dissolved in EtOAc $(40 \mathrm{~mL})$, washed with water $(2 \times 40 \mathrm{~mL})$, the organic layer dried with anhydrous sodium sulphate and the solvent removed under reduced pressure. Flash column

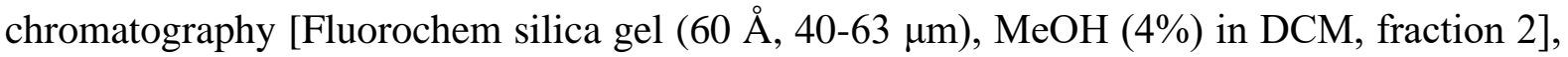
followed by trituration with diethyl ether, led to the corresponding product as a white powder. 
3,3-Bis(4-methoxyphenyl)-8-(4-pyridyl)-3H-naphtho[2,1-b]pyran 56. White powder [(132.8 mg, 67\% using KF 1.5 equiv); (59.1 mg, 59\% using KF 3.0 equiv)]; m.p. = 180-184 ${ }^{\circ} \mathrm{C} ; v_{\max }\left(\right.$ neat) $1581,1505,1462,1303,1250,1173,1032,999,955,810,787,725,552 \mathrm{~cm}^{-1}$; Photomerocyanine $\lambda_{\max }=482 \mathrm{~nm}(\mathrm{PhMe}) ;{ }^{1} \mathrm{H} \mathrm{NMR}\left(400 \mathrm{MHz}, \mathrm{CDCl}_{3}\right) \delta_{\mathrm{H}} 3.77(\mathrm{~s}, 6 \mathrm{H}, \mathrm{OMe})$, $6.25(\mathrm{~d}, 1 \mathrm{H}, J=10.0 \mathrm{~Hz}, 2-\mathrm{H}), 6.85$ (app. d, 4H, $\left.J=8.8 \mathrm{~Hz}, 3^{\prime}, 5^{\prime}, 3^{\prime \prime}, 5^{\prime \prime}-\mathrm{H}\right), 7.22(\mathrm{~d}, 1 \mathrm{H}, J=$ $8.8 \mathrm{~Hz}, 5-\mathrm{H}), 7.29$ (d, 1H, J=10.0 Hz, 1-H), 7.39 (app. d, 4H, J=8.8 Hz, 2', 6', 2", 6"-H), 7.59 (d, 2H, J=5.3 Hz, 2"', 6"'-H), 7.71-7.75 (m, 2H, 6, 9-H), 7.99 (app. s, 1H, 7-H), 8.05 (d, 1H, $J=8.8 \mathrm{~Hz}, 10-\mathrm{H}), 8.67\left(\mathrm{~d}, 2 \mathrm{H}, J=5.3 \mathrm{~Hz}, 33^{\prime \prime \prime}, 5^{\prime \prime \prime}-\mathrm{H}\right) \mathrm{ppm} ;{ }^{13} \mathrm{C}\left\{{ }^{1} \mathrm{H}\right\} \mathrm{NMR}\left(100 \mathrm{MHz}, \mathrm{CDCl}_{3}\right)$ $\delta_{\mathrm{C}} 55.3,82.5,113.4,114.0,118.9,119.3,121.5,122.5,125.1,127.0,128.4,128.5,129.3,129.9$, 130.3, 133.0, 137.0, 148.1, 150.3, 151.4, 159.0 ppm; HRMS (ESI) m/z: $[\mathrm{M}+\mathrm{H}]^{+}$Calcd for $\mathrm{C}_{32} \mathrm{H}_{2} \mathrm{NO}_{3}{ }^{+}$472.1907; Found 472.1900.

\section{Associated Content}

Supporting Information

The Supporting Information is available free of charge on the ACS Publications website at DOI: $10.1021 /$ acs.joc.xxxxxx.

Description of Kinetics Experiments, ${ }^{1} \mathrm{H}$ and ${ }^{13} \mathrm{C}\left\{{ }^{1} \mathrm{H}\right\}$ NMR Spectra, Mass Spectral Data for compounds 22, 29, 30, 32, 34, 35, 36, 38, 40, 41, 42, 46, 48, 50, 52, 55 and 56. Selected 2D NMR Spectra for compound 40 (PDF)

Author Information

Corresponding Authors

${ }^{*+}$ E-mail: Orlando.DeAzevedo@hud.ac.uk

*‡ E-mail: M.Heron@hud.ac.uk 


\section{ORCID}

Orlando De Azevedo: 0000-0003-0109-3555

Mark Heron: 0000-0002-2675-1369

Notes

The authors declare no competing financial interest.

\section{Acknowledgements}

Dr Orlando de Azevedo thanks the University of Huddersfield for financial support for this project.

\section{References and Notes}

${ }^{1}$ (a) Uchuskin, M.G.; Shcherbinin, V.A.; Butin, A.V. Synthesis and Transformations of Naphtho[2,3-b]Furans, Chem. Heterocyc. Compd., 2014, 50, 619-633. (b) Son, J.K.; Jung, S.J.; Jung, J.H.; Fang, Z.; Lee, C.S.; Seo, C.S.; Moon, D.C.; Min, B.S.; Kim, M.R.; Woo, M.H. Anticancer constituents from the roots of Rubia cordifolia L., Chem. Pharm. Bull., 2008, 56, $213-$ 216. (c) Tatum, J.H.; Baker, R.A.; Berry, R.E. Naphthofurans produced by Fusarium oxysporum isolated from citrus, Phytochemistry, 1987, 26, 2499-2500. (d) Murakami, C.; Lago, J.H.G.; Perazzo, F.F.; Ferreira, K.S.; Lima, M.E.L.; Moreno, P.R.H.; Young, C.M.M. Chemical Composition and Antimicrobial Activity of Essential Oils from Chromolaena laevigata during Flowering and Fruiting Stages, Chem. Biodivers., 2013, 10, 621-627.

${ }^{2}$ Vagdevi, H.M.; Vaidya, V.P. Studies in naphthofurans: part III - synthesis of 2-substituted naphtho[2,1-b]furans, 2-(2'-aryl-3'-acetyl-1',3',4'-oxadiazolyl)aminonaphtho[2,1- $b]$ furans and their biological activities, Ind. J. Heterocyclic Chem., 2001, 10, 253-260. 
${ }^{3}$ Arnaise, S.; Boeuf, H.; Buisson, J.P.; Cantat, N.; Demerseman, P.; Einhorn J.; Lamotte, G.; Lemelin, M.; Brimer, P.A.; Perdue, S.W.; Hsie, A.W.; Royer, R.; Kelly F.; Hofnung, M. Genotoxic activities of 2-nitronaphthofurans and related molecules, Mutagenesis, 1986, 1, $217-229$.

${ }^{4}$ Lee, K.; Huang, B. Synthesis and cytotoxic evaluation of $\alpha$-methylene- $\gamma$-butyrolactone bearing naphthalene and naphtho[2,1-b]furan derivatives, Eur. J. Med. Chem., 2002, 37, 333338.

${ }^{5}$ Srivastava, V.; Negi, A.S.; Kumar, J.K.; Faridi, U.; Sisodia, B.S.; Darokar, M.P.; Luqman, S.; Khanuja, S.P.S. Synthesis of 1-(3',4',5'-trimethoxy)phenyl naphtho[2,1,b]furan as a novel anticancer agent, Bioorg. Med. Chem. Lett., 2006, 16, 911-914.

${ }^{6}$ Caboni, L.; Kinsella, G.K.; Blanco, F.; Fayne, D.; Jagoe, W.N.; Carr, M.; Williams, D.C.; Meegan, M.J.; Lloyd, D.G. "True" Antiandrogens-Selective Non-Ligand-Binding Pocket Disruptors of Androgen Receptor-Coactivator Interactions: Novel Tools for Prostate Cancer, J. Med. Chem., 2012, 55, 1635-1644.

${ }^{7}$ Yeh, J.; Coumar, M.S.; Horng, J.; Shiao, H.; Kuo, F.; Lee, H.; Chen, I.; Chang, C.; Tang, W.; Tseng, S.; Chen, C.; Shih, S.; Hsu, J.T.A.; Liao, C.; Chao, Y.; Hsieh, H. Anti-Influenza Drug Discovery: Structure-Activity Relationship and Mechanistic Insight into Novel Angelicin Derivatives, J. Med. Chem., 2010, 53, 1519-1533.

${ }^{8}$ Lasne, C.; Lowy, R.; Venegas, W. In vitro induction of sister-chromatid exchanges after G0 exposure of human lymphocytes to five naphthofurans, Mutagenesis, 1989, 4, 27-30.

${ }^{9}$ Le Guével, R.; Oger, F.; Lecorgne, A.; Dudasova, Z.; Chevance, S.; Bondon, A.; Barath, P.; Simonneaux, G.; Salbert, G. Identification of small molecule regulators of the nuclear receptor HNF4 $\alpha$ based on naphthofuran scaffolds, Bioorg. Med. Chem., 2009, 17, 7021-7030. 
${ }^{10}$ Reichstein, A.; Vortherms, S.; Bannwitz, S.; Tentrop, J.; Prinz, H.; Müller, K. Synthesis and Structure-Activity Relationships of Lapacho Analogues. 1. Suppression of Human Keratinocyte Hyperproliferation by 2-Substituted Naphtho[2,3-b]furan-4,9-diones, Activation by Enzymatic One- and Two-Electron Reduction, and Intracellular Generation of Superoxide, J. Med. Chem., 2012, 55, 7273-7284.

${ }^{11}$ Gao, W.; Vo, G.; Howard Jr., M.H.; Wu, W.; Herron, N., PCT Int. Appl., WO 2017/210072 A1, 2017.

${ }^{12}$ (a) Peng, H.; Luan, X.; Qiu, L.; Li, H.; Liu, Y.; Zou, Y. New naphtho[1,2-b:5,6- $b$ ']difuran based two-dimensional conjugated small molecules for photovoltaic application, Opt. Mater., 2017, 72, 147-155; (b) Li, H.; Li, L.; Luan, X.; Peng, H.; Zou, Y. A novel small molecule based on naphtho[1,2-b:5,6- $\left.b^{\prime}\right]$ difuran for efficient photovoltaics, Sol. Energy, 2018, 173, $1107-1114$.

${ }^{13}$ Nakanishi, K.; Sasamori, T.; Tokitoh, N.; Kawabata, T.; Tsubaki, K. Synthesis and Properties of Butterfly-Shaped Expanded Naphthofuran Derivatives, J. Org. Chem, 2014, 79, 2625-2631. ${ }^{14}$ Sho, I.; Ryo, M.; Atsuhisa, M.; Aya, I.; Klaus, E.M.; Jun-Ichi, H. Compound, Organic Semiconductor Material Containing Same, Organic Semiconductor Ink, And Organic Transistor, WO. Pat., WO2015137304, 2015.

${ }^{15}$ (a) Mitsui, C.; Soeda, J.; Miwa, K.; Tsuji, H.; Takeya, J.; Nakamura, E. Naphtho[2,1-b:6,5$b^{\prime}$ ]difuran: A Versatile Motif Available for Solution-Processed Single-Crystal Organic FieldEffect Transistors with High Hole Mobility, J. Am. Chem. Soc., 2012, 134 5448-5451; (b) Nakano, M.; Shinamura, S.; Houchin, Y., Osaka, I.; Miyazaki, E.; Takimiya, K. Angularshaped naphthodifurans, naphtho[1,2-b;5,6- $\left.b^{\prime}\right]$ - and naphtho[2,1- $\left.b ; 6,5-b^{\prime}\right]$-difuran: are they isoelectronic with chrysene?, Chem. Commun., 2012, 48, 5671-5673. 
${ }^{16}$ Majumdar, K.C.; Chattopadhyay, B.; Chakravorty, S. An Expedient Synthesis of Bis-Fused Benzofuran and a Two-Directional Ring-Closing Metathesis for the Synthesis of Bisbenzoxepines and Bisbenzoxocines, Synthesis, 2009, 0674-0680.

17 Murakami, K.; Yorimitsu, H.; Osuka, A. Practical, Modular, and General Synthesis of Benzofurans through Extended Pummerer Annulation/Cross-Coupling Strategy, Angew. Chem. Int. Ed., 2014, 53, 7510-7513.

${ }^{18}$ (a) Aiken, S.; Gabbutt, C.D.; Heron, B.M.; Kolla, S.B. Photochromic bi-naphthopyrans, Dyes Pigm., 2015, 113, 239-250; (b) Gabbutt, C.D.; Heron, B.M.; Kilner C.; Kolla, S.B. Benzopentalenonaphthalenones from the intramolecular capture of a merocyanine derived from a naphthopyran, Chem. Commun., 2010, 46, 8481-8483; (c) Gabbutt, C.D.; Hepworth, J.D.; Heron, B.M.; Thomas, D.A.; Kilner, C.; Partington, M., Synthesis and photochromic properties of methoxy substituted 2,2-diaryl-2H-naphtho[1,2-b]pyrans, Heterocycles, 2004, 63, 567-582; (d) Moustrou, C., Rebière, N.; Samat, A.; Guglielmetti, R.; Yassar, A.E.; Dubest, R.; Aubard, J. Synthesis of thiophene-substituted 3H-naphtho[2,1-b]pyrans, precursors of photomodulated materials, Helv. C. Acta, 1998, 81, 1293-1302; (e) Pozzo, J.-L.; Samat, A.; Guglielmetti, R.; Dubest R.; Aubard, J. Synthesis and photochromic behavior of naphthopyrans, pyranoquinolines, pyranoquinazolines, and pyranoquinoxalines, Helv. Chim. Acta, 1997, 80, 725-738; (f) Gemert, B.V.; Bergomi, M.; Knowles, D. Photochromism of diarylnaphthopyrans, Mol. Cryst. Liq. Cryst., 1994, 246, 67-73; (g) Heller, H.G.; Oliver, S.N.; Whittall, J.; Tomlinson, I. Photochromic spiropyran compounds, U.S. Pat., US4826977, 1989. ${ }^{19}$ Dmitrieva, N.D.; Liberzon R.M.; Ryabokobylko, Y.S. Conversion of spiro[(1,2-dihydro-3Hbenzo[h]chromene)-3,9'-xanthenes] to 9-(2-naphtho[2,1-b]furyl)xanthenes, Zh. Org. Khim., 1985, 21, 1340-1345. 
${ }^{20}$ Sastry, M.N.V.; Claessens, S.; Habonimana, P.; De Kimpe, N. Synthesis of the Natural Products 3-Hydroxymollugin and 3-Methoxymollugin, J. Org. Chem., 2010, 75, 2274-2280.

${ }^{21}$ Yaragorla, S.; Khan, T. An unexpected thermal-ring-rearrangement of benzochromenes to inden-3-yl-naphthols with p-TsOH, Org. Biomol. Chem., 2018, 16, 7920-7025.

${ }^{22}$ Gabbutt, C.D.; Heron, B.M.; Kolla, S.B.; Kilner, C.; Coles, S.J.; Horton, P.N., Hursthouse, M.B. Ring contraction during the $6 \pi$-electrocyclisation of naphthopyran valence tautomers, Org. Biomol. Chem., 2008, 6, 3096-3104.

${ }^{23}$ Menon, R.S.; Findlay, R.S.; Bissember A.C.; Banwell. The Au(I)-Catalyzed Intramolecular Hydroarylation of Terminal Alkynes Under Mild Conditions: Application to the Synthesis of 2H-Chromenes, Coumarins, Benzofurans, and Dihydroquinolines, M.G. J. Org. Chem., 2009, 74, 8901-8903.

${ }^{24}$ Gabbutt, C.D.; Heron, B.M.; Kilner C.; Kolla, S.B. The synthesis and photochromism of a 2,2-diaryl-6-styryl-2H-[1]benzopyran: Unexpected palladium-mediated ring-contraction of a 6-bromo-2,2-diaryl-2H-[1]benzopyran, Dyes Pigm., 2012, 92, 825-830.

${ }^{25}$ Böttcher, C.; Zeyat, G.; Ahmed, S.A.; Irran, E.; Cordes, T.; Elsner, C.; Zinth, W.; Braun, K.R. Synthesis of novel photochromic pyrans via palladium-mediated reactions, Beilstein J. Org. Chem., 2009, 5, doi: 10.3762/bjoc.5.25, number 25.

${ }^{26}$ (a) Aiken, S.; Cano, J.P.; Gabbutt, C.D.; Heron, B.M.; Kosa, T.; Su, L.; Sukhomlinova, L.; Taheri, B. 3H-Naphtho[2,1-b]pyrans As Photochromic Dichroic Dyes and Optical Articles Containing Them, PCT Int. Appl. WO2008030226, 2008; (b) Yao, Q.; Kinney, E.P.; Yang, Z. Ligand-Free Heck Reaction: $\mathrm{Pd}(\mathrm{OAc})_{2}$ as an Active Catalyst Revisited, J. Org. Chem., 2003, $68,7528-7531$ 
${ }^{27}$ Pentsak, E.O.; Eremin, D.B.; Gordeev, E.G.; Ananikov, V.P. Phantom Reactivity in Organic and Catalytic Reactions as a Consequence of Microscale Destruction and ContaminationTrapping Effects of Magnetic Stir Bars, ACS Catal., 2019, 9, 3070-3081.

${ }^{28}$ (a) Leadbeater, N.E.; Marco, M. Transition-metal-free Suzuki-type coupling reactions, Angew. Chem. Int. Ed., 2003, 42, 1407-1409; (b) Leadbeater, N.E.; Marco, M. TransitionMetal-Free Suzuki-Type Coupling Reactions: Scope and Limitations of the Methodology, J. Org. Chem., 2003, 68, 5660-5667.

${ }^{29}$ Schettini, R.; Sicignano, M.; De Riccardis, F.; Izzo, I.; Della Sala, G. Macrocyclic Hosts in Asymmetric Phase-Transfer Catalyzed Reactions, Synthesis, 2018, 50, 4777-4795.

${ }^{30}$ Ortica, F. The role of temperature in the photochromic behaviour, Dyes Pigm., 2012, 92, $807-816$.

${ }^{31}$ (a) Gericke, R.; Lues, I., Tetrahedron Lett., The transformation of a chromene derivative into benzofurans via allene intermediates, 1992, 33, 1871-1874; (b) Gaertner, R. The equilibrium between the $o$-allenylphenoxide and 2-benzofurylmethyl anions, J. Am. Chem. Soc., 1951, 73, $4400-4404$.

${ }^{32}$ Pérez-Lorenzo, M. J. Phys. Chem. Lett., Palladium Nanoparticles as Efficient Catalysts for Suzuki Cross-Coupling Reactions, 2012, 3, 167-174

${ }^{33}$ Gabbutt, C.D.; Heron, B.M.; Instone, A.C.; Thomas, D.A.; Partington, S.M., Hursthouse, M.B., Gelbrich, T. Observations on the synthesis of photochromic naphthopyrans, Eur. J. Org. Chem., 2003, 1220-1230.

34 Proutiere, F.; Schoenebeck, F. Solvent Effect on Palladium-Catalyzed Cross-Coupling Reactions and Implications on the Active Catalytic Species, Angew. Chem. Int. Ed., 2011, 50, 8192-8195. 
${ }^{35}$ (a) Joly, D.; Kervella, Y.; Demadrille, R. Organic Photochromic Dye And Uses Thereof For Dye Sensitized Solar Cells, PCT Int. Appl., WO2018215371 A1, 2018; (b) Arai, K.; Kobayashi, Y.; Abe, J. Rational molecular designs for drastic acceleration of the color-fading speed of photochromic naphthopyrans, Chem. Comm., 2015, 51, 3057-3060; (c) Aiken, S.; Gabbutt, C.D.; Heron, B.M.; Kershaw, C.S.; Smith, N.J.; Cano, J-P. Photochromic Dichroic Naphtho-Pyrans And Optical Articles Containing Them, US Patent, US8703978 B2, 2014; (d) Aiken, S.; Cano, J-P.; Gabbutt, C.D.; Heron, B.M. 6-(Biphenyl-ester)-3H-Naphtho[2,1b]pyrans As Photochromic Dichroic Dyes and Optical Articles Containing Them, US Patent, US8436184 B2, 2013; (e) Blackwell, C.J.; Gabbutt, C.D.; Guthrie, J.T.; Heron, B.M. The synthesis and properties of vinyl substituted naphthopyrans and their styrene copolymers, Dyes Pigm., 2012, 95, 408-420.

36 Cotterill, W.D.; Livingstone, R.; Walshaw, M.V. 1,3- and 3,3Bis(methoxyphenyl)naphtho[2, 1-b]pyrans, J. Chem. Soc., C, 1970, 13, 1758-1764.

${ }^{37}$ Rickwood, M.; Smith, K.E.; Gabbutt, C.D., Hepworth, J.D., PCT Int. Appl., WO 9422850 A1, 1994.

${ }^{38}$ Moustrou, C.; Rebiere, N.; Samat, A.; Guglielmetti, R.; Yassar, A.E.; Dubest, R.; Aubard, J. Synthesis of Thiophene-Substituted 3H-Naphtho[2,1-b]pyrans, Precursors of Photomodulated Materials, Helv. Chim. Acta, 1998, 81, 1293-1302.

${ }^{39}$ Barachevskii, V.A.; Ayt, A.O.; Gorelik, A.M.; Kobeleva, O.I.; Valova, T.M.; Venidiktova, O.V.; Popova, G.V. Russ. Pat., RU 2526176 C2, 2014.

${ }^{40}$ Zhao, W.; Carreira, E.M. Facile one-pot synthesis of photochromic pyrans, Org. Lett., 2003, $5,4153-4154$. 
${ }^{41}$ Aiken, S.; Booth, K.; Gabbutt, C.D.; Heron, B.M.; Rice, C.R.; Charaf-Eddin, A., Jacquemin, D. The first structural and spectroscopic characterisation of a ring-opened form of a $2 \mathrm{H}$ naphtho[1,2-b]pyran: a novel photomerocyanine, Chem. Commun., 2014, 50, 7900-7903.

${ }^{42}$ Aiken, S.; Allsopp, B.; Booth, K.; Gabbutt, C.D.; Heron B.M.; Rice, C.R. 5-Hydroxy substituted naphthofurans and naphthothiazoles as precursors of photochromic benzochromenes, Tetrahedron, 2014, 70, 9352-9358. 